UNITED STATES DEPARTMENT OF THE INTEIOR

GEOLOGICAL SURVEY

Geophysical Wel1-Log Measurements

in Three Drill Holes at Salt Valley, Utah

by

Jeffrey J. Daniels, Robert J. Hite, and James H. Scott

Open-File Report $\frac{81-36}{}$

1980

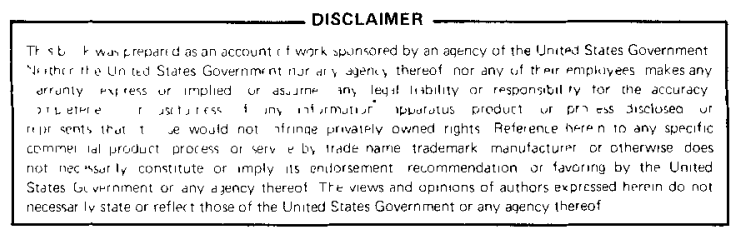

This report is preliminary and has not been edited or reviewed for conformity with U.S. Geological Survey standards. 


\section{DISCLAIMER}

This report was prepared as an account of work sponsored by an agency of the United States Government. Neither the United States Government nor any agency Thereof, nor any of their employees, makes any warranty, express or implied, or assumes any legal liability or responsibility for the accuracy, completeness, or usefulness of any information, apparatus, product, or process disclosed, or represents that its use would not infringe privately owned rights. Reference herein to any specific commercial product, process, or service by trade name, trademark, manufacturer, or otherwise does not necessarily constitute or imply its endorsement, recommendation, or favoring by the United States Government or any agency thereof. The views and opinions of authors expressed herein do not necessarily state or reflect those of the United States Government or any agency thereof. 


\section{DISCLAIMER}

Portions of this document may be illegible in electronic image products. Images are produced from the best available original document. 
CONTENTS

Page

Abstract . . . . . . . . . . . . . . . . . . . . . . . . 1

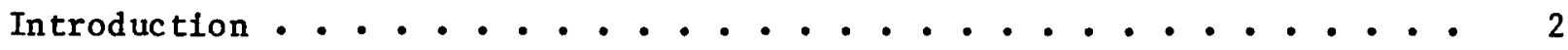

Geophysical well-log response in evaporites. . . . . . . . . . . . . 3

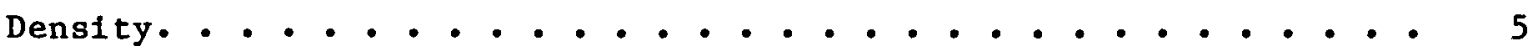

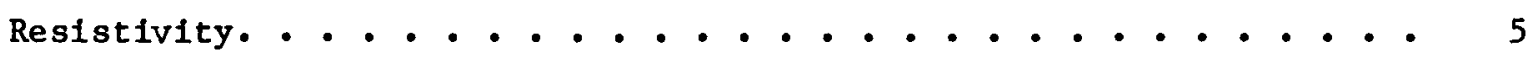

Gamma-ray . . . . . . . . . . . . . . . . . . . . 6

Neutron. . . . . . . . . . . . . . . . . . . . . . 6

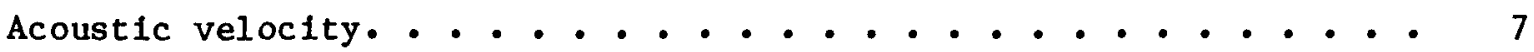

Interpretation of 11thologies from borehole geophysical

we11 logs at Salt Valley . . . . . . . . . . . . . . . . 7

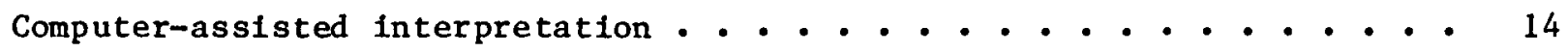

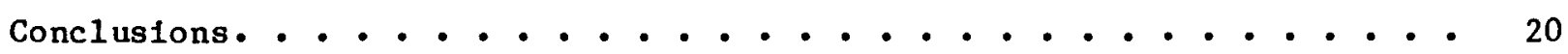

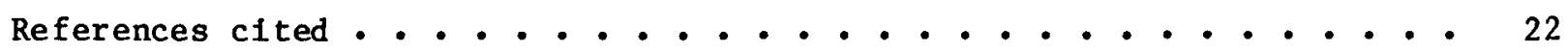

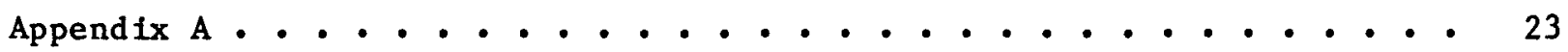

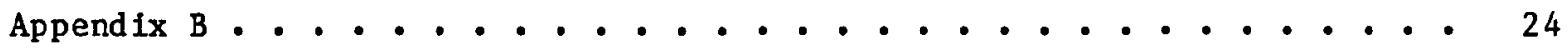

Append1x C • • • • • • • • • • • • • • • • • • • • • • • • 25

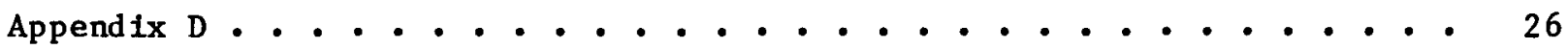




\title{
Geophysical We11-Log Measurements
}

in Three Drill Holes at Salt Valley, Utah

by

Jeffrey J. Daniels, Robert J. Hite, and James H. Scott

U.S. Geological Survey, Denver, Colorado 80225

\begin{abstract}
Three exploratory drill holes (DOE Salt Valley No. 1, No. 2, and No. 3) were drilled at Salt Valley, Utah, to study the geologic, physical, geochemical, and hydrologic properties of the evaporite sequence in the Permian Paradox Member of the Hermosa Formation. The results of these studies will be used to help to determine the sultability of salt deposits in the Paradox basin as a storage medium for radioactive waste material.

The following geophysical well-log measurements were made in each of the three drill holes: (1) density, (2) neutron, (3) acoustic velocity, (4) normal resistivity, and (5) gamma ray. Widely spaced resistivity and conductivity well-log measurements were made in the deep drill hole (DOE No. 3). Each of these well-log measurements shows the division of the evaporite sequence into halite and interbed sections. At the present time the most useful well-logging measurements for determining the individual 1ithologies in an evaporite sequence are gamma ray, neutron, density, and acoustic velocity •

The high resistivity contrast between the drilling fluid $(0.5 \mathrm{ohm}-\mathrm{m})$ and salt $(10,000 \mathrm{ohm}-\mathrm{m})$ makes it difficult to obtain quantitative measurements of electrical properties in an evaporite sequence. Tests of widely spaced electrode configurations show that the effects of the brine on the resistivity measurements can be reduced, and the depth of investigation increased, by
\end{abstract}


Increasing the source-receiver electrode spacing. Tests of a single-coil Induction probe show good resolution of the contrasting electrical properties of the various interbed 1ithologies.

\section{INTRODUCTION}

During the summer and fall of 1978 three holes were drilled by the U.S. Department of Energy at Salt Valley, Utah, to study the geologic and hydrologic characteristics of the evaporite sequence in the Permian Paradox Member of the Hermosa Formation. The approximate depths of these three drill holes are as follows: (1) DOE Salt Valley No. 1 (SV1) was drilled to a depth of approximately $390 \mathrm{~m}$, (2) DOE Salt Valley No. 2 (SV2) was drilled to a depth of approximately $375 \mathrm{~m}$, and (3) DOE Salt Valley No. 3 (SV3) was drilled to a depth of approximately $1240 \mathrm{~m}$.

Borehole geophysical measurements were made (using U.S. Geological Survey borehole geophysical equipment and contract equipment) in each drill hole before casing was set (at the top of the salt), and in the remaining open hole after the drilling was completed. These measurements were made in order to better understand the physical properties of the various lithologies associated with the evaporite sequence. Geophysical well-logging information is necessary to Interpret deep-penetration geophysical measurements (such as hole-to-surface and hole-to-hole electrical measurements) that can be used to evaluate the geologic viability of a site whthout extensive drilling • 
GEOPHYSICAL WELL-LOG RESPONSE IN EVAPORITES

A general analysis of the well-log response measurements from drill hole SV3 was given in a previous paper (Daniels and others, 1979). Some of these data are repeated in this report.

The evaporite sequence at Salt Valley can be divided into three different stratigraphic regimes as follows: (1) a weathered caprock, (2) halite sectlons below the caprock, and (3) interbeds of anhydrite, shale, and dolomite separating the halite sections. Figure 1 illustrates an idealized geologic section showing typical evaporites in the Paradox basin. This evaporite sequence is repeated in a cyclic manner as a result of salinity changes in the basin during deposition. Previous investigators (Tixier and Alger, 1970; Nurmi, 1978) have described the basic physical properties of an evaporite sequence. These general properties, summarized in figure 1, appear to apply to the Salt Valley evaporite sequence.

A geophysical well-log measurement is a function of the physical properties of the rock framework, the fluid in the formation, conditions in the borehole (fluid and rugosity), the volume of the rock investigated by the probe, the vertical resolution of the probe (thin-bed resolution), and the design characteristics of each individual logging probe. Therefore, the response measured with a geophysical well-logging probe should always be considered an apparent, rather than a true, physical-property value. The response characteristics of individual well-logging probes can be summarized as follows: 


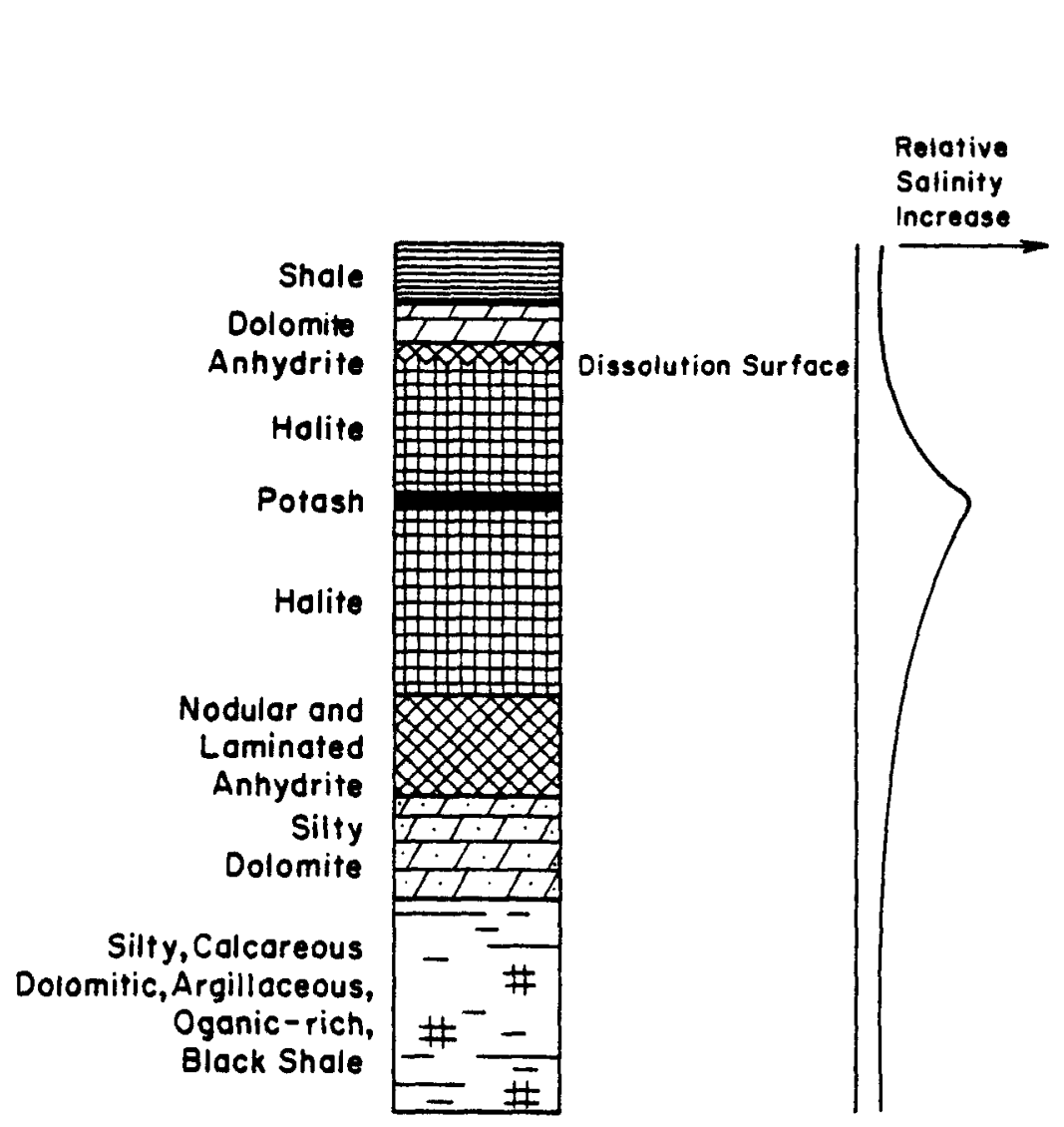

\begin{tabular}{|l|l|l|l|l|}
\multicolumn{2}{c}{$\begin{array}{l}\text { (grams/cc) } \\
\text { Density }\end{array}$} & $\begin{array}{l}\text { (km/sec) } \\
\text { Velocity }\end{array}$ & \multicolumn{1}{l}{$\begin{array}{l}\text { Notural } \\
\text { Rodiogctivify }\end{array}$} & $\begin{array}{l}\text { Water } \\
\text { Content }\end{array}$ \\
\hline Halite & 2.16 & $4.4-6.5$ & None & Very Law \\
Sylvite & 1.99 & $4.6-6.5$ & High & Low \\
Anhydrite & 2.96 & 4.1 & None & Very Low \\
Carnallite & 1.61 & $4.4-6.5$ & Low & High \\
Dolomite & 2.87 & $3.5-6.9$ & None & Low \\
Gypsum & 2.32 & $2-3.5$ & None & Infermediate \\
Shale & $2.2-2.6$ & $2.3-4.7$ & High & intermediate-High \\
\hline
\end{tabular}

Figure 1.- Lithology and physical properties of an idealized evaporite sequence in the Paradox basin. The lithologic information is Eron Hite and Lohman (1973), and the physical property information is from Tixter and Alger ( 1970$)$. 


\section{Density}

The density probe consists of a gamma-ray source and one or more gammaray detectors. Gamma rays emitted by the source are scattered by the rock formation as an inverse function of the electron density of the rocks. The Compton-scattered gamma radiation that is measured at the gamma-ray detector on the probe is inversely proportional to the electron density of the rock. When two detectors are used to measure the scattered gamma radiation, the effects of the borehole conditions (rugosity and fluid density) on the calibrated density measurement can be compensated, and the computed density is approximately equal to the bulk density of the rocks. The apparent bulk density of halite is approximately $2.05 \mathrm{~g} / \mathrm{cm}^{3}$ in the three Salt Valley drill holes. The density of the interbed and caprock 1ithologies is a function of the porosity and grain density of the rocks. Clays and shales have low apparent bulk densities (2.2 to $\left.2.6 \mathrm{~g} / \mathrm{cm}^{3}\right)$, sandstone has intermediate apparent bulk densities $\left(2.45\right.$ to $\left.2.65 \mathrm{~g} / \mathrm{cm}^{3}\right)$, and dolomite has a high apparent bulk density $\left(2.7\right.$ to $2.9 \mathrm{~g} / \mathrm{cm}^{3}$ ). Potash minerals (carnallite and sylvite) have very low apparent bulk densities (less than $2.0 \mathrm{~g} / \mathrm{cm}^{3}$ ).

\section{Resistivity}

Resistivity is a measure of the ease that electrical current passes through a rock and is a function of porosity, fluid resistivity, and grain resistivity. Laboratory resistivity measurements show a wide range of resistivity values for evaporites. The apparent resistivity of clay is usually less than $10 \mathrm{ohm}-\mathrm{m}$, shale has a resistivity of less than $50 \mathrm{ohm}-\mathrm{m}$, sandstone has a resistivity between 50 and $200 \mathrm{ohm}-\mathrm{m}$, and dolomite has a resistivity of more than $200 \mathrm{ohm}-\mathrm{m}$. The DC resisitivy of consolidated halite is generally greater than $10,000 \mathrm{ohm}-\mathrm{m}$, which contrasts markedly with the resistivities of 
the caprock and interbeds in the Paradox basin. In theory, resistivity should be an excellent indicator of resistivity contrasts. However, conventional resistivity probes are not designed to operate in holes drilled through evaporites. The resistivity contrast between the drilling fluid and the salt formation is approximately 200,000 to 1 , resulting in a resistivity response that is dominated by the low resistivity of the drilling fluid. This response results in resistivity we11-log measurements that lack detail in defining 1ithologies within the interbeds, as well as yielding apparent resistivity values that are several orders of magnitude different from the true resistivity of the salt. Conventional induction-logging tools are also inadequate for measuring the high resistivities found in an evaporite sequence.

\section{Gamma ray}

The gamma-ray probe measures the natural gamma radiation emitted by the rocks surrounding the borehole. The principal natural gamma-ray emitting minerals in the evaporite sequence are uranium and potassium-40. Halite has a nearly zero gamma-ray response, shale has a low to intermediate gamma-ray response, black shale has an intermediate to high gamma-ray response, and the potash minerals have very high gamma-ray responses.

\section{Neutron}

The neutron well-logging probe consists of a neutron source and a neutron detector located on the probe approximately $0.5 \mathrm{~m}$ from the source. The number of neutrons counted at the receiver is inversely proportional to the hydrogen content of the rocks surrounding the borehole, and is primarily a measure of the amount of water and hydrocarbons contained in the rocks. The neutron response is high in halite, intermediate in sandstone and dolomite, and low in carnallite and black shale. 
Acoustic velocity

The acoustic-velocity probe consists of an acoustic source and two (or more) acoustic detectors. The interval transit time of a sonic wave emitted from the source is measured between two detectors. The inverse of the interval transit time $(t)$ times the distance (in meters) between the two detectors is the acoustic velocity $(\mathrm{m} / \mathrm{s})$. Only the p-wave velocity is usually measured. The acoustic velocity is high for carnallite, anhydrite, and dolomite (approximately $5000 \mathrm{~m} / \mathrm{s}$ ), intermediate for halite (approximately $4500 \mathrm{~m} / \mathrm{s}$ ), and low for gypsum and shale (approximately $3000 \mathrm{~m} / \mathrm{s}$ ).

\section{INTER PRETATION OF LITHOLOGIES}

FROM BOREHOLE GEOPHYSICAL WELL LOGS AT SALT VALLEY

The complete borehole geophysical well-log measurements for the holes considered in this study are shown in the appendixes as follows: (1) the logs for DOE Salt Valley No. 1 (SV1) are in Appendix A, (2) the logs for DOE Salt Valley No. 2 (SV2) are in Append1x B, and (3) the logs for DOE Salt Valley No. 3 (SV3) are in Append $1 x$ C.

The response of the neutron, gamma-ray, density, and acoustic-velocity well logs in the halite, caprock, and interbed sections of drill hole SV 3 is illustrated in figure 2. Halite is easily distinguished from the interbeds and caprock at Salt Valley. The high gamma-ray response in the interbeds and caprock is caused by potassium-rich clays and possibly uranium in the shaley interbeds, whereas the low neutron response indicates a general increase in 

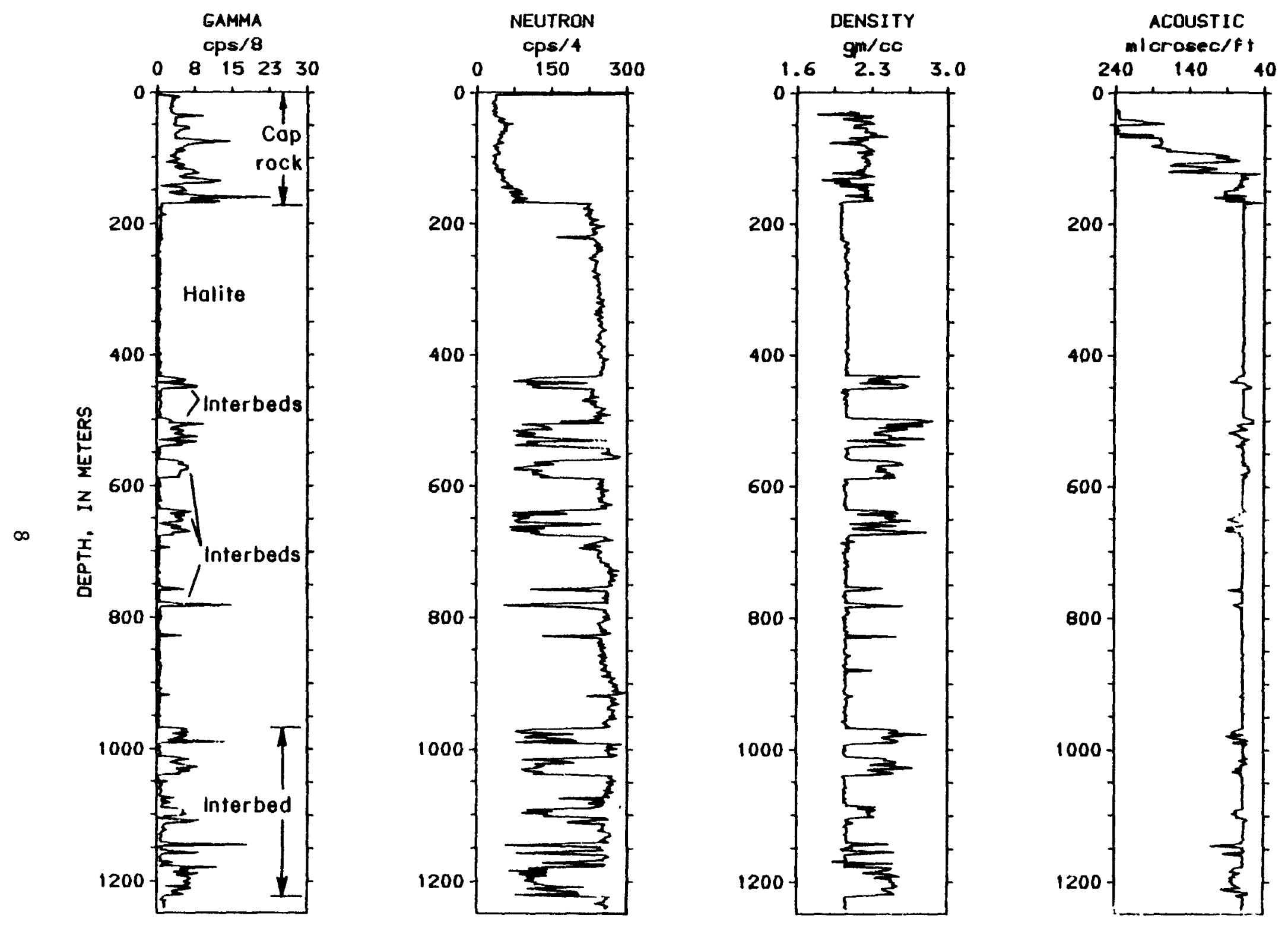

Figure 2.--Gamma ray (GAMMA), neutron (NEUTRON), compensated density (DENSITY), and acoustic-velocity (ACOUSTIC) well logs for drill hole SV3. The interbed, caprock, and halite intervals are 1ndicated on the gamma-ray log. Units are counts/second (cps) for the gamma-ray and neutron logs, grams/cubtc centimenter $\left(\mathrm{g} / \mathrm{cm}^{3}\right)$ for the density $\mathrm{log}$, and microseconds/feet (microsec/ft) for the acoustic $10 \mathrm{~g}$. 
water in the interbeds and caprock. The density log shows the relatively high grain densities of the interbeds compared to the halite, whereas the acoustic log reflects the low p-wave velocity of the caprock and interbeds. The density, neutron, and acoustic $l o g$ responses reflect the hydration of anhydrite to gypsum in the caprock.

An experiment using widely spaced electrode arrays was performed in the test well (SV3) at Salt Valley. Electrode configurations and the resulting apparent resistivities are shown in figure 3. Increasing the source-recelver separation increases the apparent resistivity. The widely spaced configurations also show more detall than the conventional long-normal resistivity. This paradox is a result of penetration of current beyond the invaded zone of the interbeds. If the electrode separation were increased further, the resolution of the interbeds would diminish, and the apparent resistivity would increase as the ratio of salt-to-interbed thickness increased. The intrinsic resistivity values of the evaporite layers can only be achieved by removing the effect of the borehole from the apparent resistivity response by detailed computer modeling.

High-frequency electromagnetic methods, such as radar, can be used in dry holes drilled into evaporites, and could be adapted to work in fluid-filled holes. More experimental work is needed to determine the usefulness of subradar-frequency electromagnetic measurements in salt environments. Figure 4 shows an uncalibrated experimental conductivity $\log$ that was made at Sa1t Valley by measuring the in-phase self-inductance of a single coil driven at a frequency of $1000 \mathrm{~Hz}$. The quadrature component of this inductance signal is normally used to measure magnetic susceptibility and has been described by 

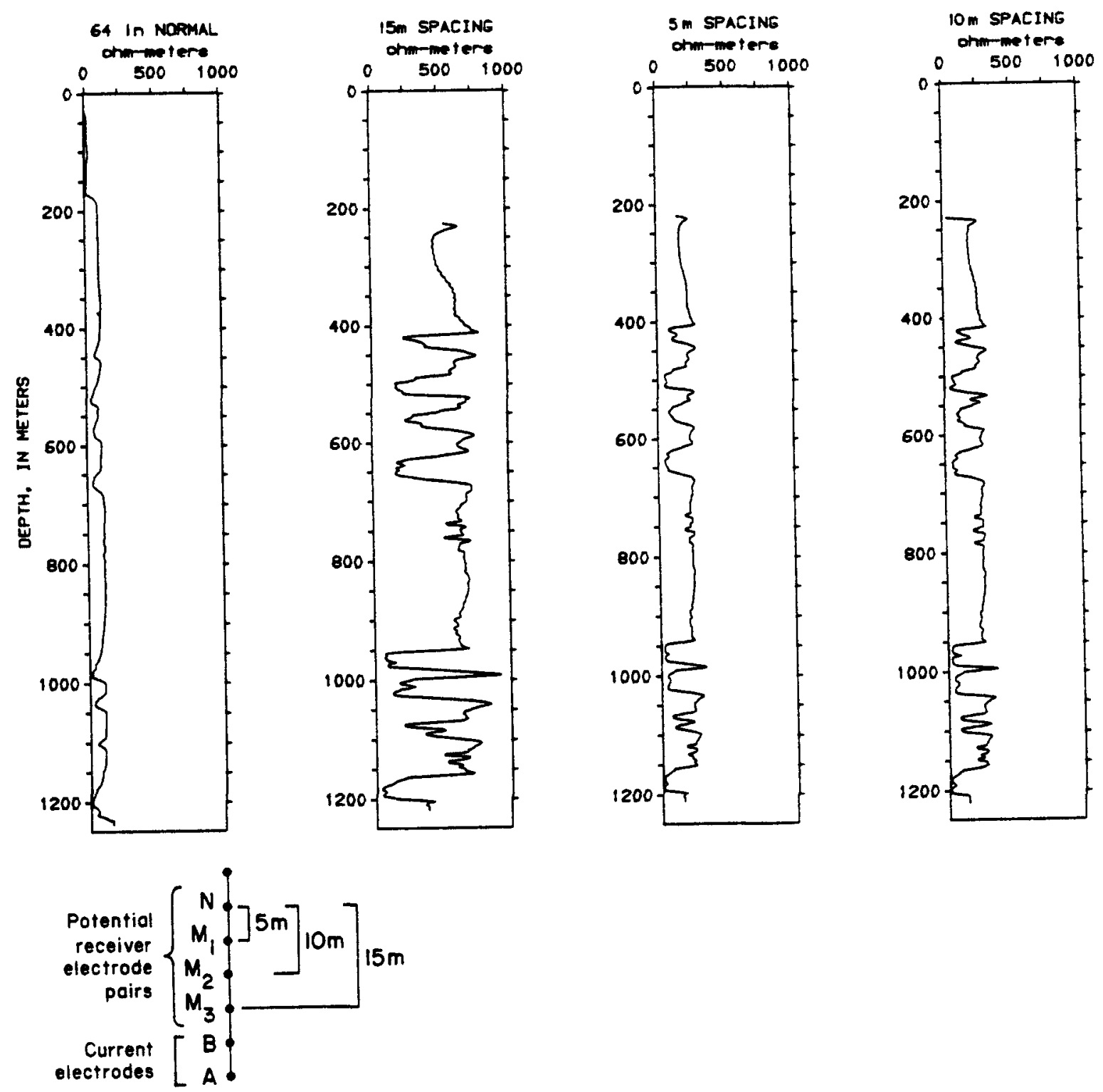

\section{Electrode Spacing}

Flgure 3.--DC-resistivity well-log responses for drill hole sv3. The long normal array (64 in) is the conventional $1.6 \mathrm{~m}$ logging array. Spacing for the other arrays are shown in the figure. Plot position for the widely spaced arrays is halfway between the potential electrodes. 

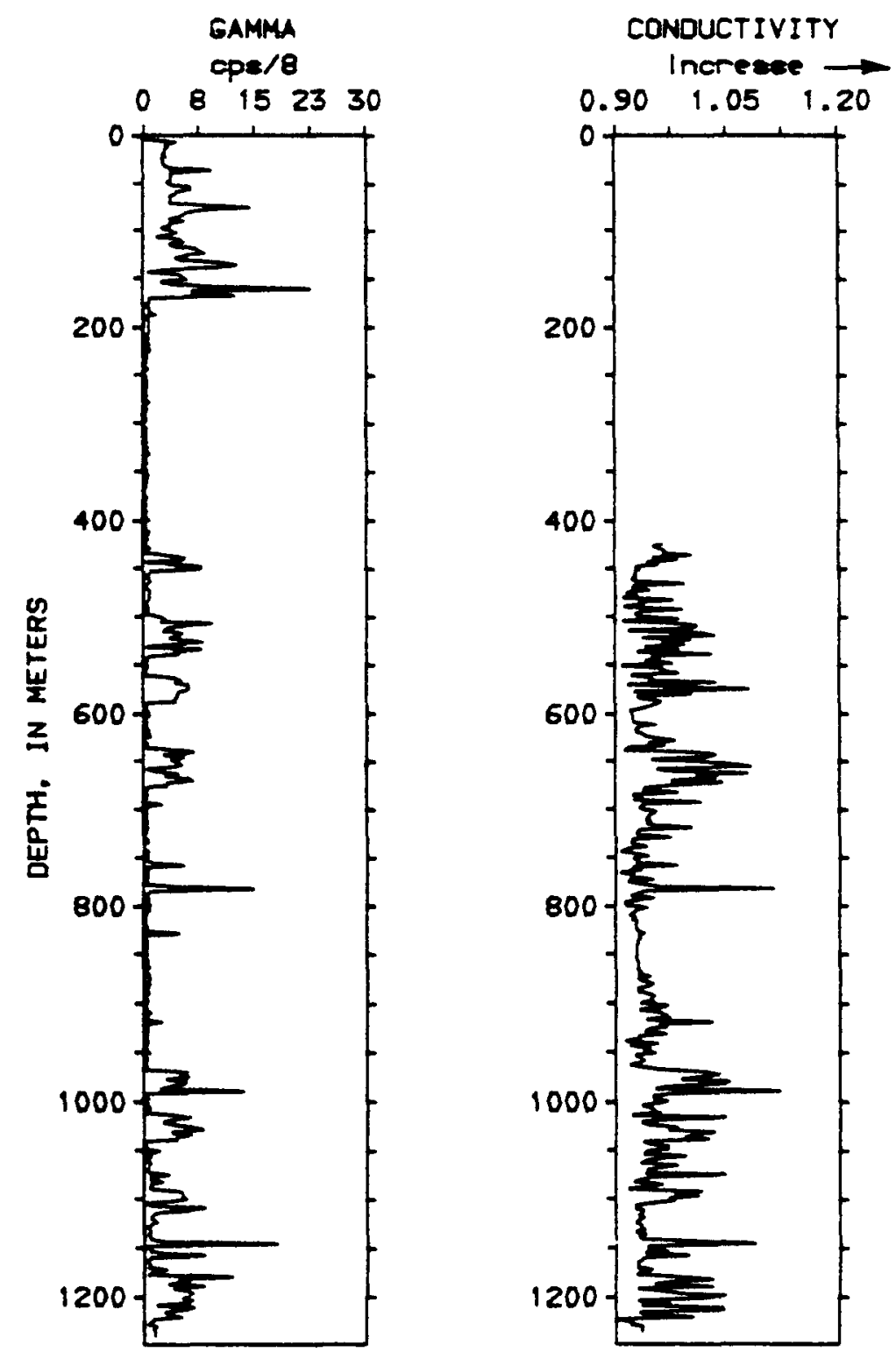

Figure 4.--Gama-ray and conductivity well logs for drili hole sv3. Conductivity values are uncalibrated. 
Scott and others (1976). The usefulness of this conductivity measurement is not yet fully established, but the measurements correlate with conductivity changes that would be expected in an evaporite sequence.

Figure 5 illustrates the well-log measurement response for a typical halite-interbed sequence from the well logs shown in figures 2 and 4. Carnallite can usually be distinguished from shale by its low density. Anhydrite can be distinguished from halite by its high density and the nearly constant acoustic velocity of halite. There are sections of the interbeds where multiple lithologies make it difficult to distinguish the mineralogic components of the section. This difficulty is clearly illustrated for depth intervals 1018 to $1025 \mathrm{~m}$ and 1030 to $1040 \mathrm{~m}$. The presence of dolomite in shale and sandstone complicates the interpretation of geophysical well logs in evaporite sequences, Halite, shale, potash, and anhydrite can be easily identified by individual well logs as follows:

(1) Anhydrite has a low gamma-ray count, high neutron response, high acoustic velocity, high density, and low conductivity.

(2) Most black shales have a high gamma-ray response, low neutron response, intermediate densities, low acoustic velocities, and high conductivities.

(3) Halite has a low gamma-ray count, high neutron response, low density, low acoustic velocity, and low conductivity.

(4) The potash minerals at Salt Valley are carnallite and sylvite. Carnallite has an intermediate gamma-ray count, an intermediate neutron response, low density, high acoustic velocity, and high 

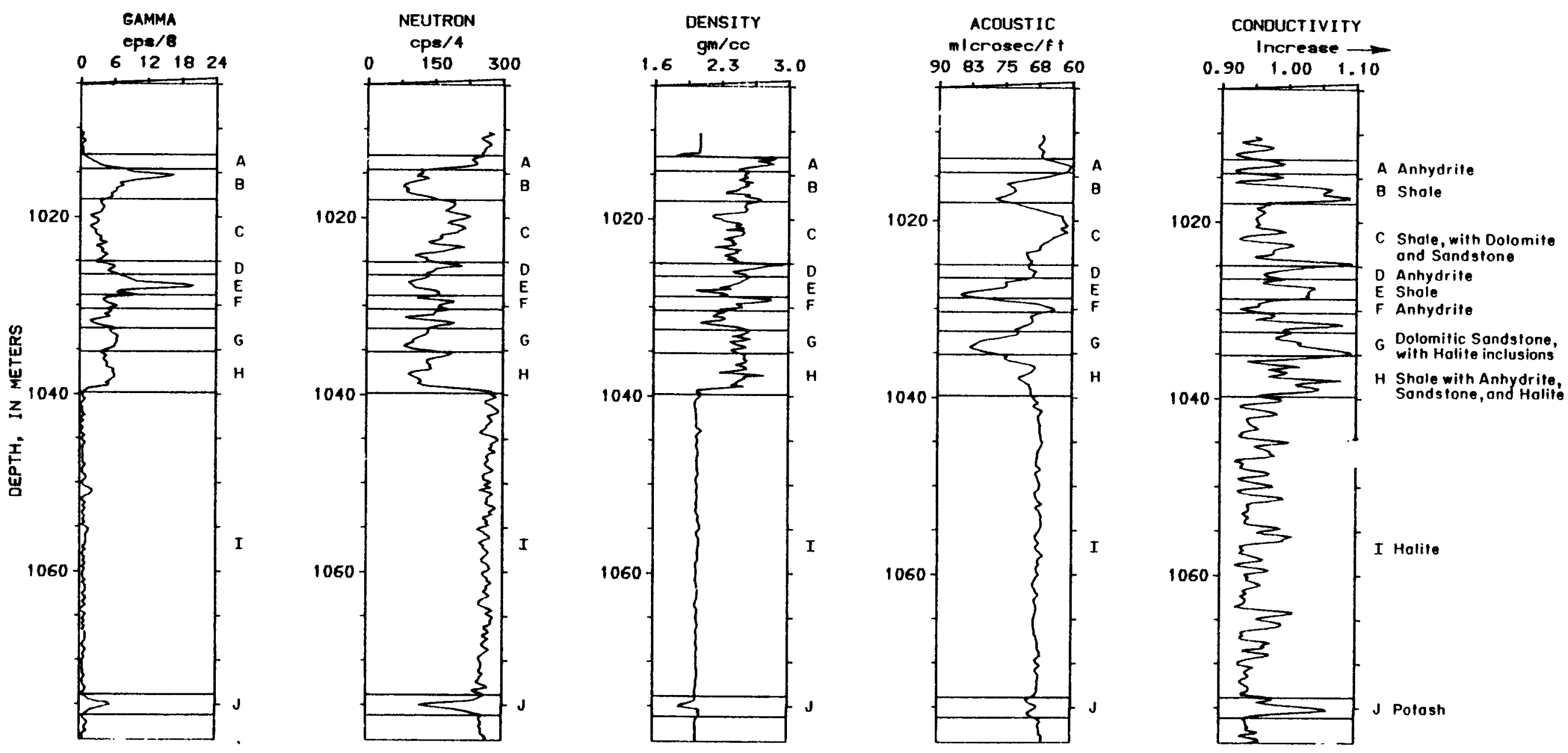

Figure 5.-Lithologies corresponding to response values for the gamma-ray, neutron, density, acoustic-velocity, and conductivity well logs. 
conductivity. Sylvite has a high gamma-ray count, high neutron response, low density, high acoustic velocity, and low conductivity.

COMPUTER-ASSISTED INTER PRETATTION

To overcome the ambiguity associated with individual well-1og interpretation, several well logs must be simultaneously interpreted. A consistent interpretation of the well logs can be achieved by interpreting the digital well-log data. Computer-assisted interpretation of well logs involves the following procedure: (1) Input of digital depth-well log response measurement data pairs into the computer, (2) assignment of value ranges of one or more geophysical well logs for a particular 1ithology, and (3) execution of the computer program to assign lithologies to depth intervals where the well-log measurements are within the specified ranges for a particular lithology. This interpretation procedure is necessarily subjective; it should be considered to be a preliminary interpretation that should be refined by visual interpretation of the geophysical well logs. A computerassisted interpretation of drill hole SV3 is given in Appendix D. The 1ithologles shown in Appendix D were interpreted using the well-log response value ranges given in table 2. The well-log response measurements of the Salt Valley drill holes were digitized at depth intervals of $0.1524 \mathrm{~m}$. Therefore, beds whose thickness is less than approximately $0.3048 \mathrm{~m}$ cannot be detected. Beds whose thickness is less than approximately $0.6096 \mathrm{~m}$ show no response on the lithologic well logs in Appendix D. However, the 1ist of interpreted values, shown in Appendix D, does add information to the interpretation for thin beds. 
The caprock 1ithology is complex, conststing of a heterogenous mixture of sandstone, shale, dolomite, and gypsum. Vertical and horizontal changes in the stratigraphy are difficult to define. The complex nature of the caprock is reflected in the geophysical well-log measurements. The gamma-ray, neutron, density, acoustic-velocity, and caliper well logs for the caprock depth intervals in drill holes SV1, SV2, and SV3 are shown in figures 6,7 , and 8 , respectively. The interpreted 1ithology based upon the well-1og responses is shown below the geophysical well logs. The Iithologic well logs were interpreted using the we11-log response value ranges given in table 2. The computer was programmed to assign a specific lithology to all depth intervals that contained well-log response values in a specified value range. The interpretation assumes that the only lithologies present in the section are those that are listed in the table. Other 11thologies may be present but have not been considered in this interpretation. This interpretation should be considered as a first approximation of the 1ithology and not a final interpretation of the 1ithology. However, the well-log interpretation does indicate the following :

(1) The gamma-ray well logs indicate the presence of more shale in drill hole SV1 than in drill holes SV2 or SV3.

(2) The shale at a depth of $121 \mathrm{~m}$ in SV1, $103 \mathrm{~m}$ in SV2, and $135 \mathrm{~m}$ in SV3 may be a single, correlative, lithologic unit.

(3) The neutron well logs indicate that the caprock in drill hole SVI has a lower porosity than in drill holes SV1 or SV2.

Only the neutron and gamma-ray well logs were used in the interpretation. The caliper log shows that each of the holes has large changes in borehole 

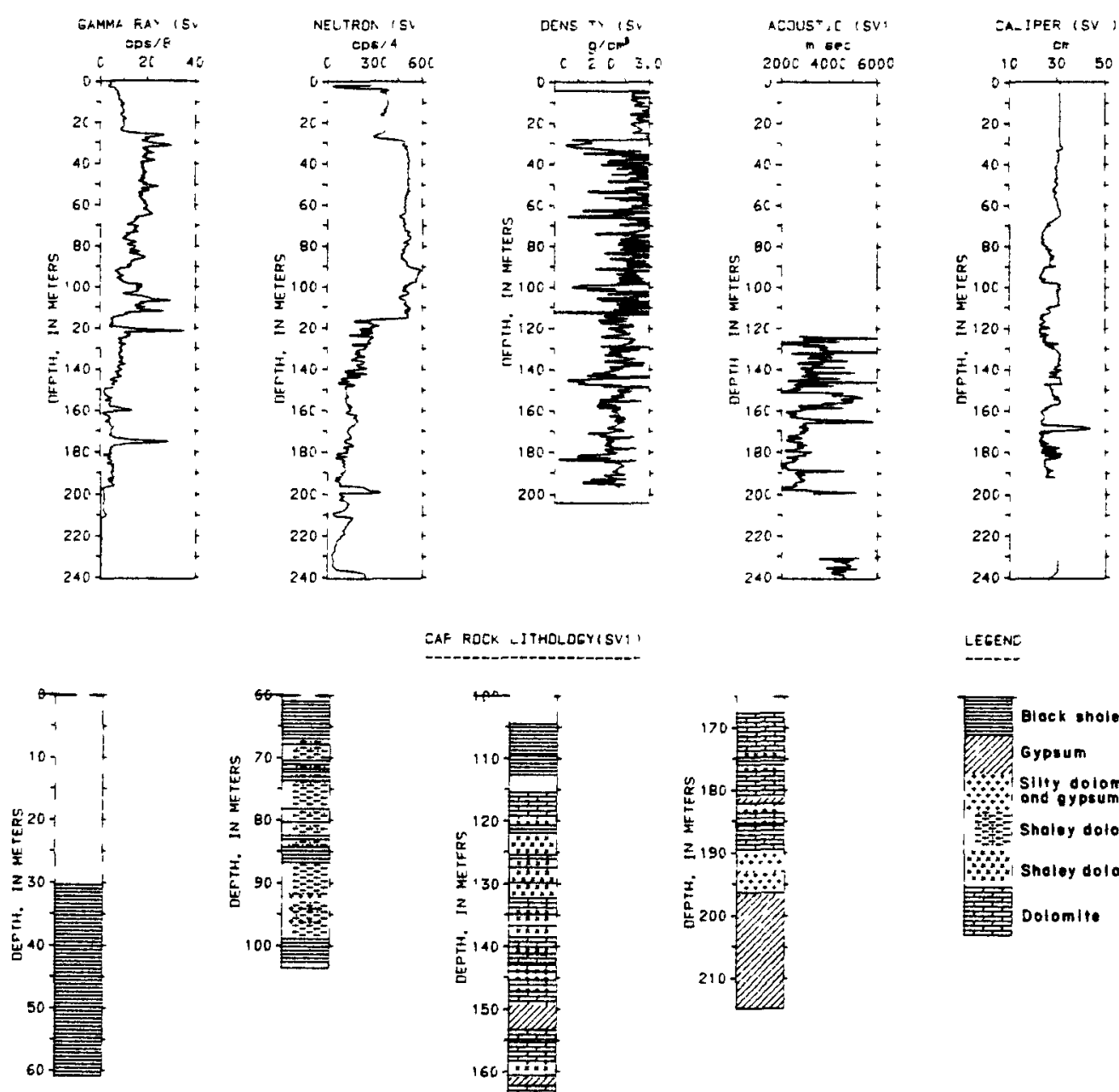

CAF ROEK LITHOLOGYISUI,

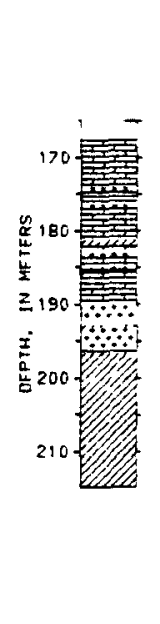

LESENE
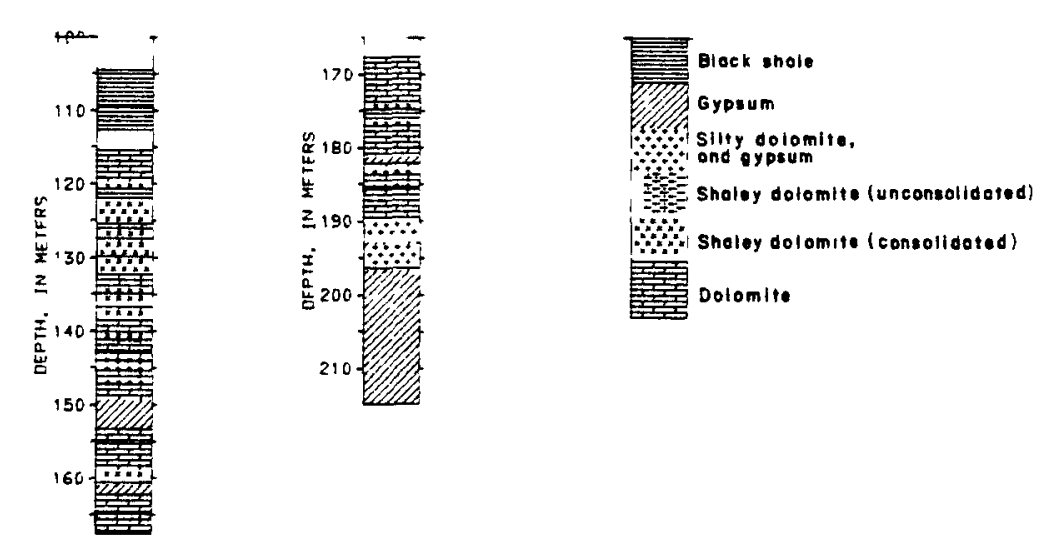

Figure 6.--Gama-ray, neutron, density, acoustic-velocity, and caliper well logs for drill hole SVl. Iithologic interpretation for the caprock in SVI based upon the information in table 1. 

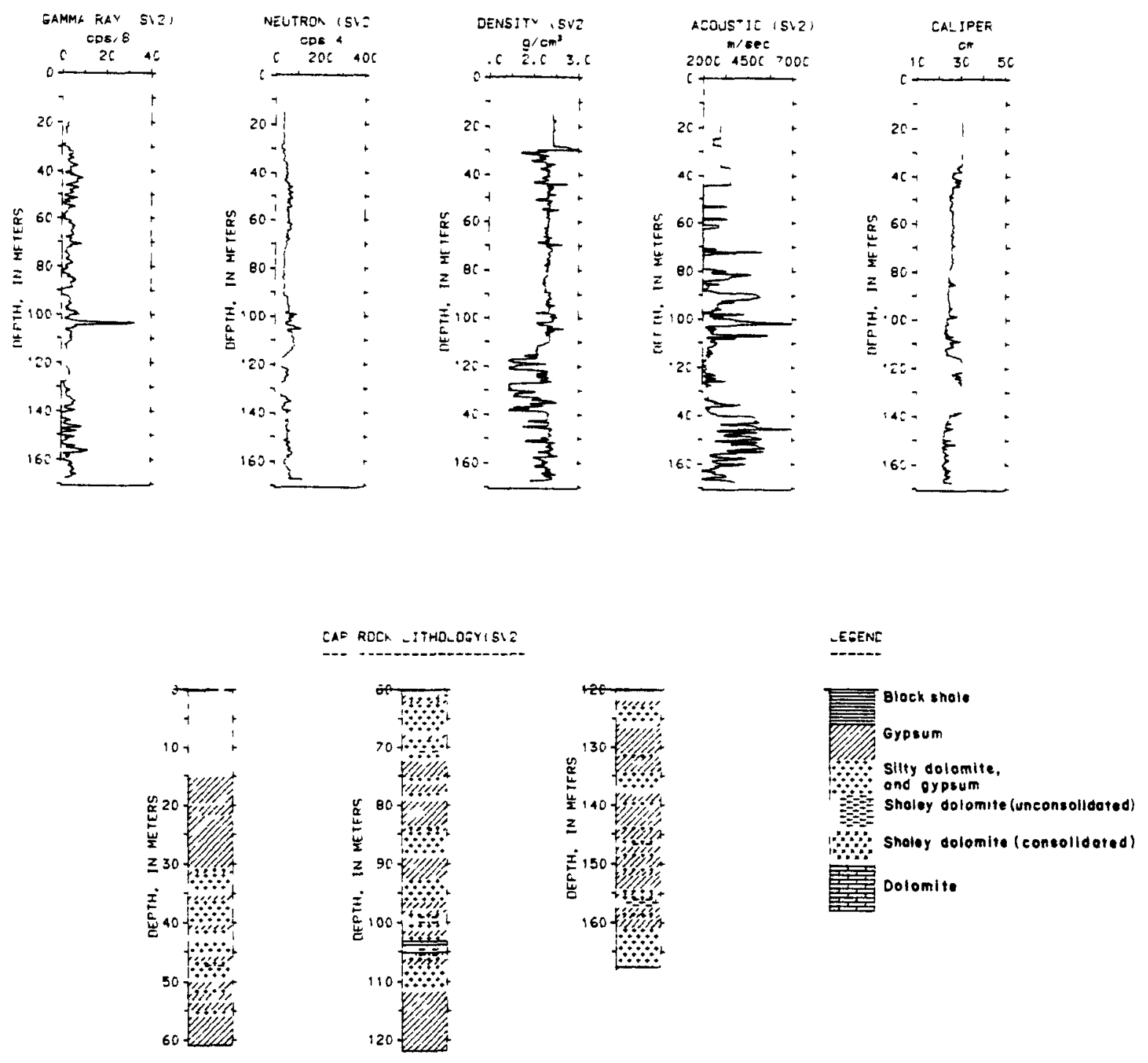

Figure T.--Gama-ray, seutron, density, acoustic-velocity, and caliper well logs for drill hole SV2. Lithologic interpretation for the caprock in SV2 based upon the information in tabie?. 

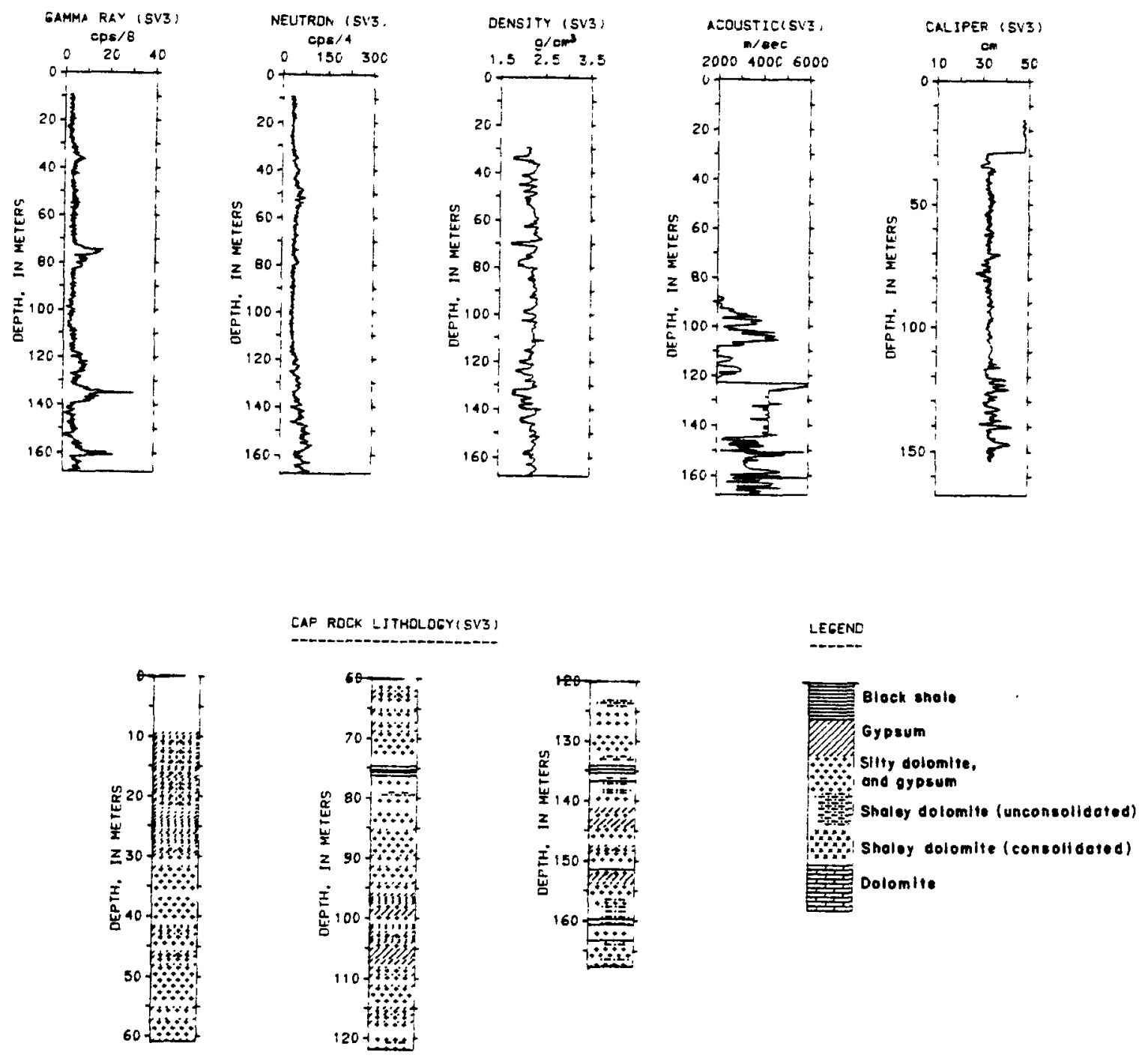
Figure 8.-Gama-ray, neutron, density, acoustic-velocity, and caliper well logs for drill hole SV3. Iithologic interpretation for the caprock in SV3 based upon the information in table 1.


rugosity. These variations in borehole rugosity introduce errors in all of the logs except the gamma-ray well log. These errors are particularily pronounced on the acoustic velocity and density well logs.

Table 1.-We11-log response value ranges for interpreting lithologies in the hal1te-interbed sequence in drill hole SV3

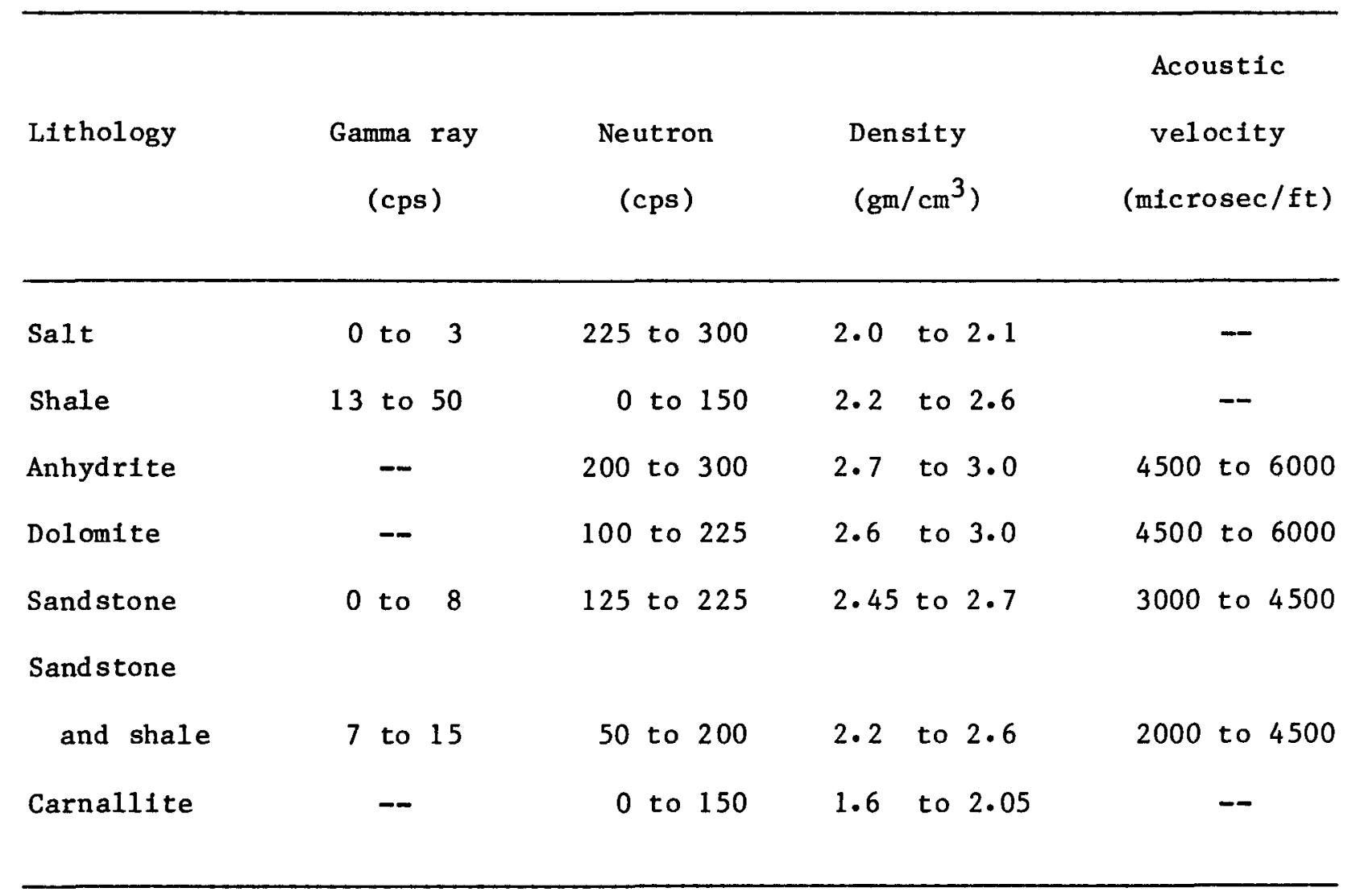


Table 2.-Value ranges used for computer-assisted interpretation of interbed lithologies

\begin{tabular}{lcc}
\hline & Gamma ray & Neutron \\
$\begin{array}{l}\text { Lithology } \\
\text { cps/8 }\end{array}$ & cps/4 \\
\hline $\begin{array}{l}\text { Black shale } \\
\text { Gypsum }\end{array}$ & 15 to 50 & 0 to 1000 \\
$\begin{array}{l}\text { Silty dolomite } \\
\text { and gypsum }\end{array}$ & 3 to 8 & 0 to 1000 \\
$\begin{array}{l}\text { Dolomite } \\
\text { (consolidated) }\end{array}$ & 3 to 8 & 1 less than 100 \\
Shaley dolomite & 8 to 15 & greater than 100 \\
(unconsolidated) & 7 to 15 & 50 to 125 \\
Shaley dolomite & &
\end{tabular}

\section{CONCLUS IONS}

The lithologies present in an evaporite sequence (halite, anhydrite, potash, shale, gypsum, sandstone, and dolomite) show physical-property characteristics that are easily identiflable on conventional well logs. However, the evaporite sequence at Salt Valley is lithologically and structurally complex. More work needs to be done to quantitatively identify the mineralogic components within the complex interbed sequences. This is particularly true for the caprock; at the present time, interpretation of the caprock 
lithology is little more than an educated guess. The lithology could be identified by conducting detafled chemical and petrographic analysis of core taken from the caprock.

The thin beds in the interbed sequence can be better defined by obtaining very closely spaced digital geophysical well-log measurements (a sample spacing of less than $2 \mathrm{~cm}$ ). However, quantitative identification of mineralogic components within the interbed sequence may require the development and application of new borehole geophysical tools. Some tools that are presently used (such as acoustic velocity, neutron, and density) have been developed for use in ofl exploration and may be redesigned to give the detalled information required for the nuclear waste program.

Borehole geophysical probes are needed to measure the large contrast of electrical properties (dielectric constant and resistivity) that are present between the individual lithologic components in an evaporite sequence. The single-coil induction probe that was tested at Salt Valley may be useful in determining the moisture content of halite. Both dry-hole and wet-hole radar, and subradar-frequency electromagnetic borehole probes need to be developed. 


\section{REF ERENCES CITED}

Daniels, J. J., Scott, J. H., and Hite, R. J., 1979, Analysis of borehole geophysical data in an evaporite sequence at Salt Valley, Utah: Society of Professional We11-Log Analyst Twentieth Annual Logging Symposium, June 3-6, 1979, Transactions, $19 \mathrm{p}$.

Hite, R. J., and Lohman, S. W., 1973, Geologic appraisal of Paradox basin salt deposits for waste emplacement: U.S. Geological Survey open-file report, $68 \mathrm{p} \cdot$

Nurmi, R. D., 1978, Use of well logs in evaporite sequences: Society of Economic Paleontologists and Mineralogists short course 4, Marine evaporites, Transactions, $95 \mathrm{p}$.

Scott, J. H., Summers, G. C., and Barth, J. J., 1976, A magnetic-susceptibility well-logging system for mineral exploration: Soclety of Exploration Geophysicists, 46th Annual International Meeting Programs (Abstract WP-37), Houston, Texas, October 24-28, 1976.

Tixier, M. P., and Alger, R. P., 1970, Log evaluation of nonmetallic mineral deposits: Geophysics, v. 35, no. 1, p. 124-142. 
APPENDIX A

Geophysical Well Logs from DOE Salt Valley No. 1 Drill Hole (SV1) 


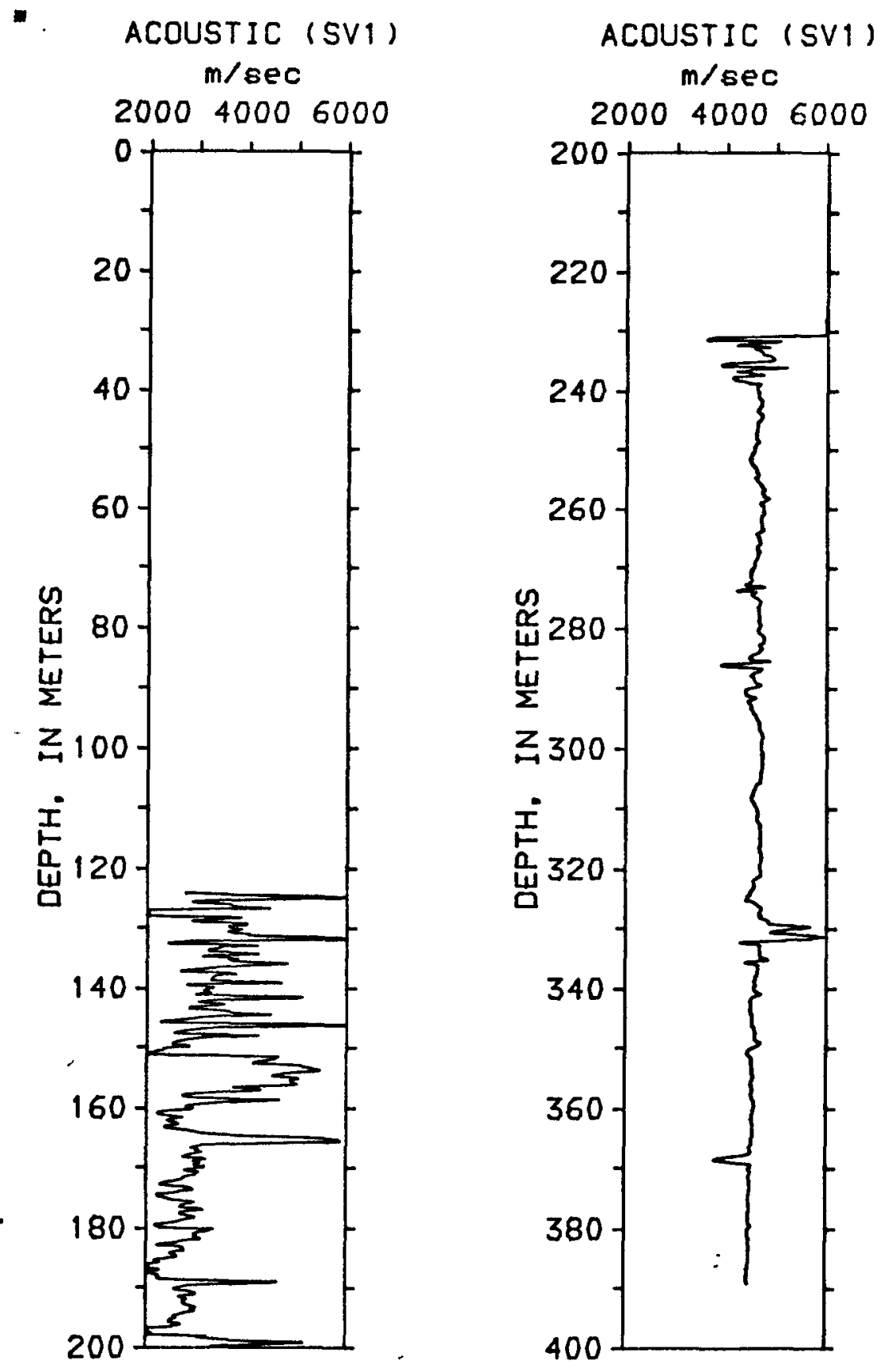
Figure Al.-Acoustic velocity well log for drill hole sVl. Units are in
meters/second $(\mathrm{m} / \mathrm{sec})$. 

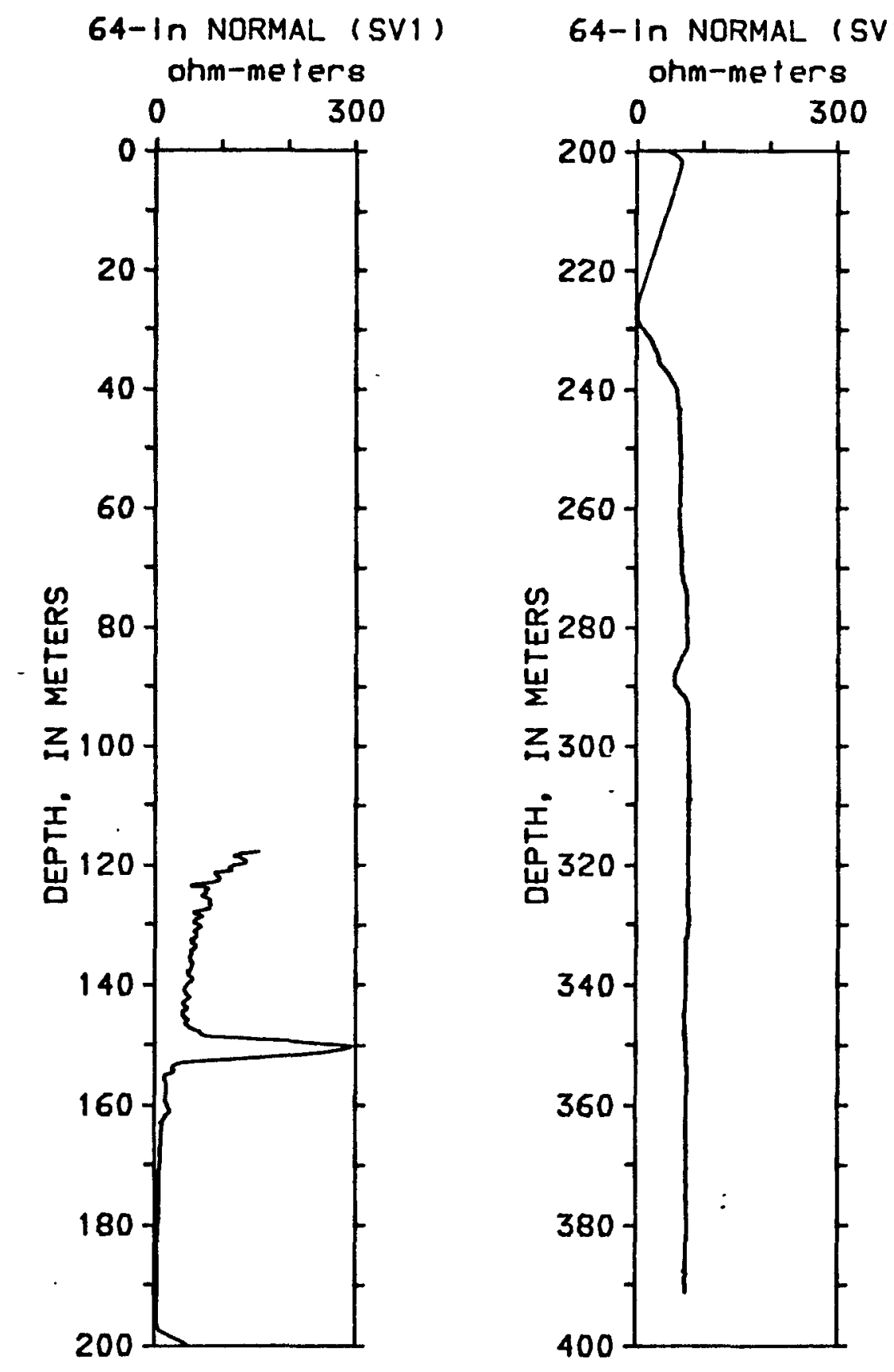

Figure A2.--Normal reststivity well $\log (64 \mathrm{ln})$ for dr1ll hole sV1. Units are In ohm-meters. 

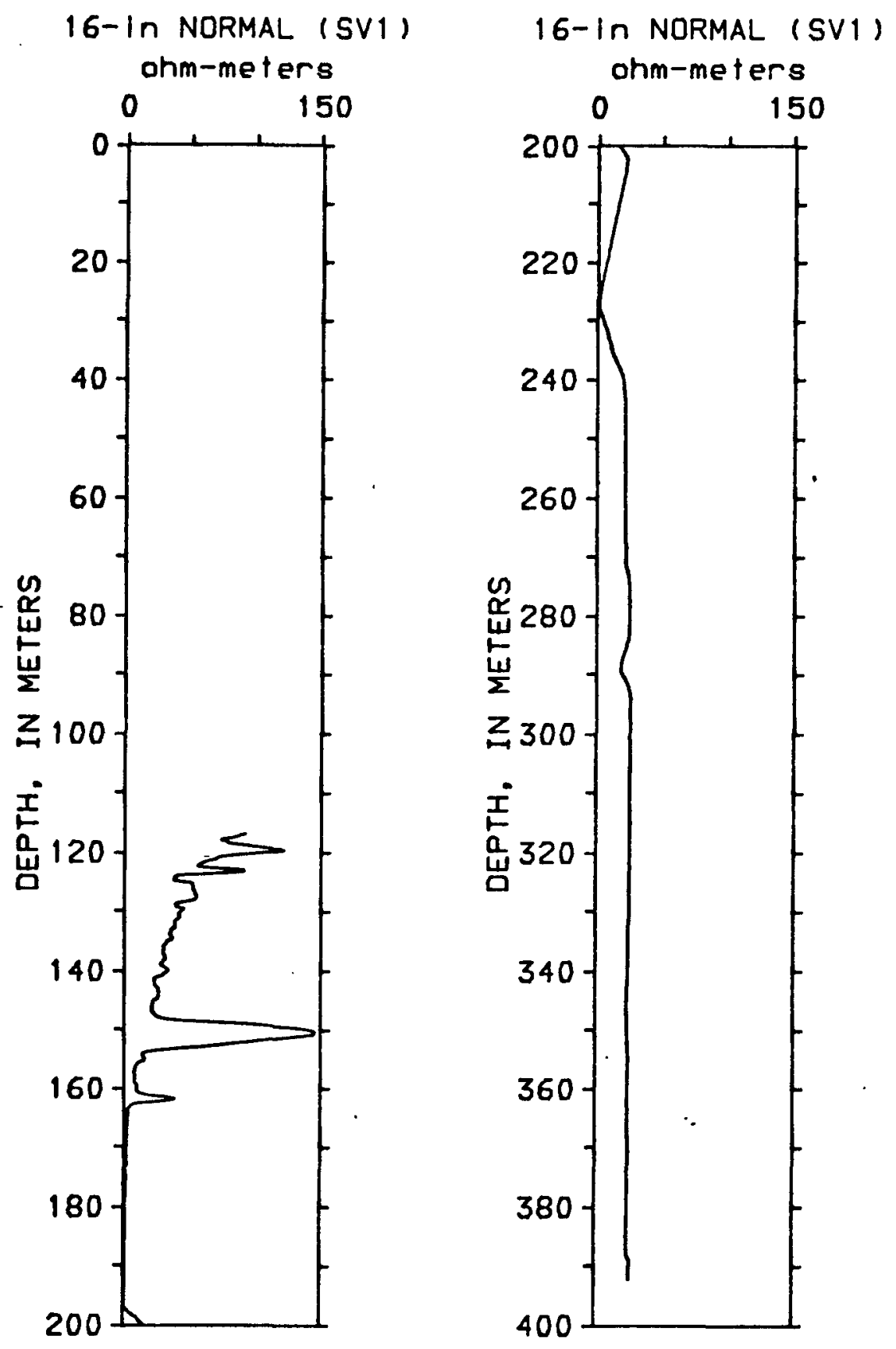

Figure A3.--Normal resistivity $108(16 \mathrm{ln})$ for SV1. Units are in ohm-meters. 

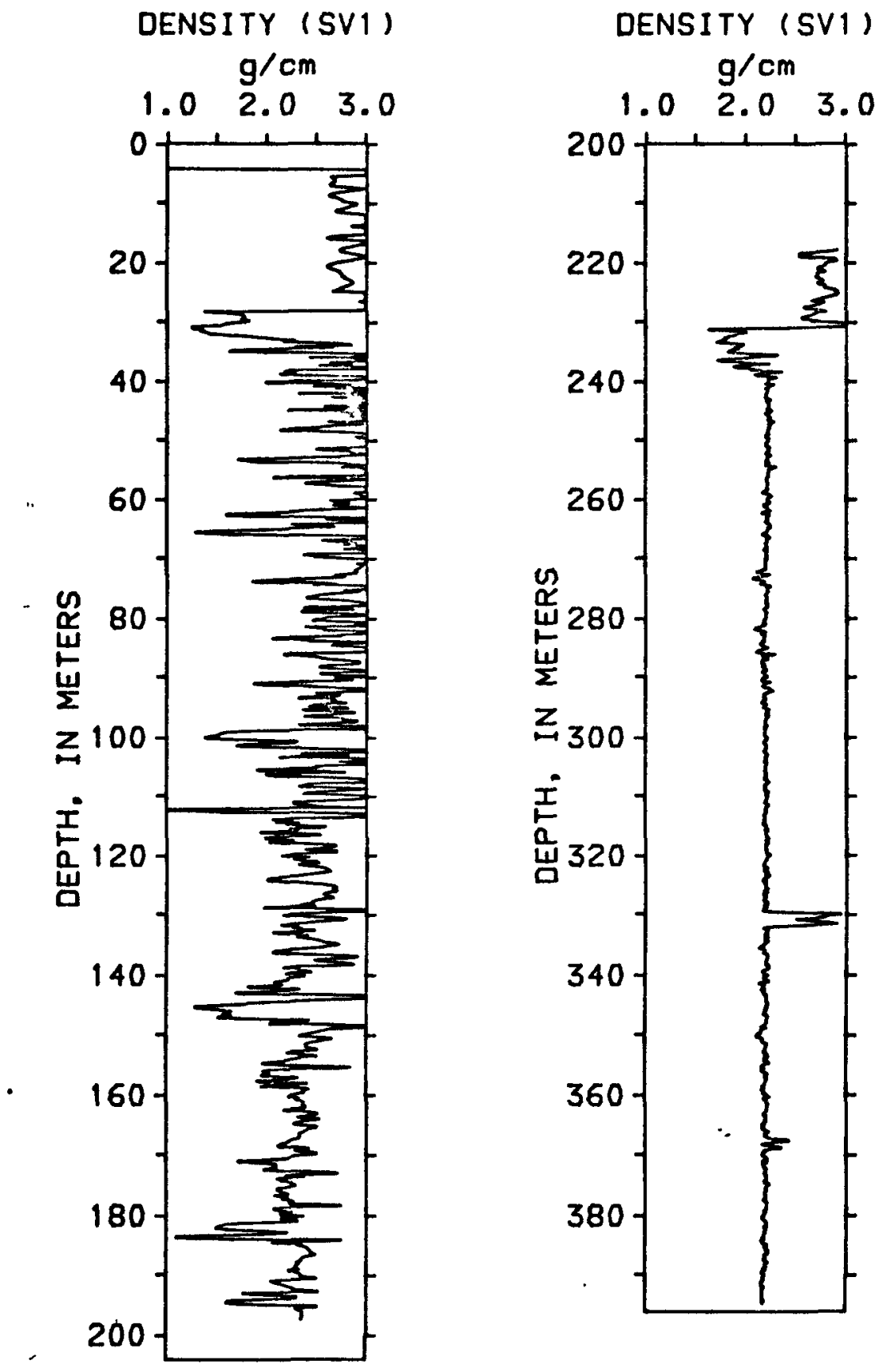

Figure A4.--Bulk density geophysical well log for drill hole $\dot{s} 1$. Units are in grams/centimeter ${ }^{3}\left(\mathrm{~g} / \mathrm{cm}^{3}\right)$. 

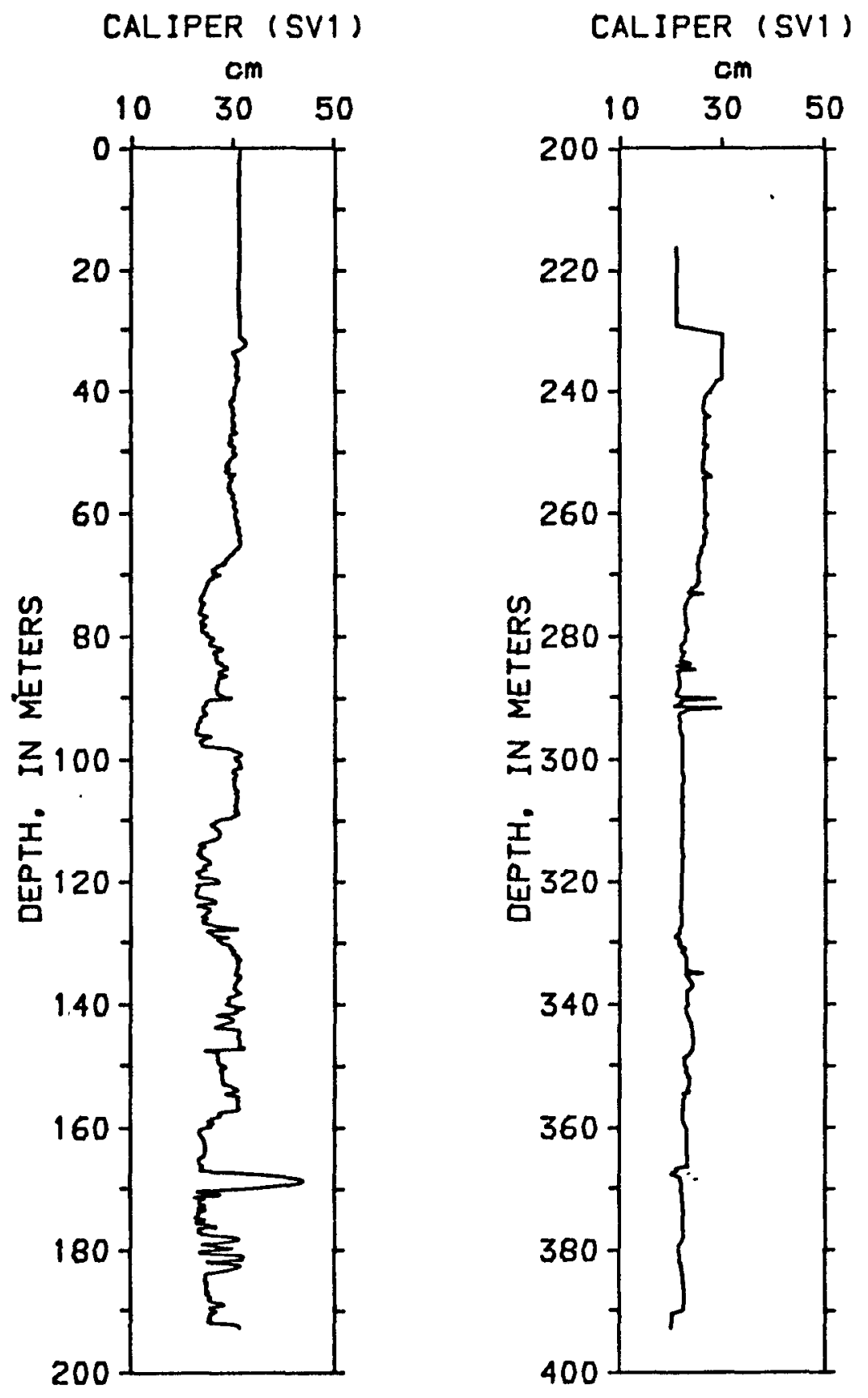

Figure A5.-Callper well log for drill hole SV1. Units are in centimeters
$(\mathrm{cm})$. 

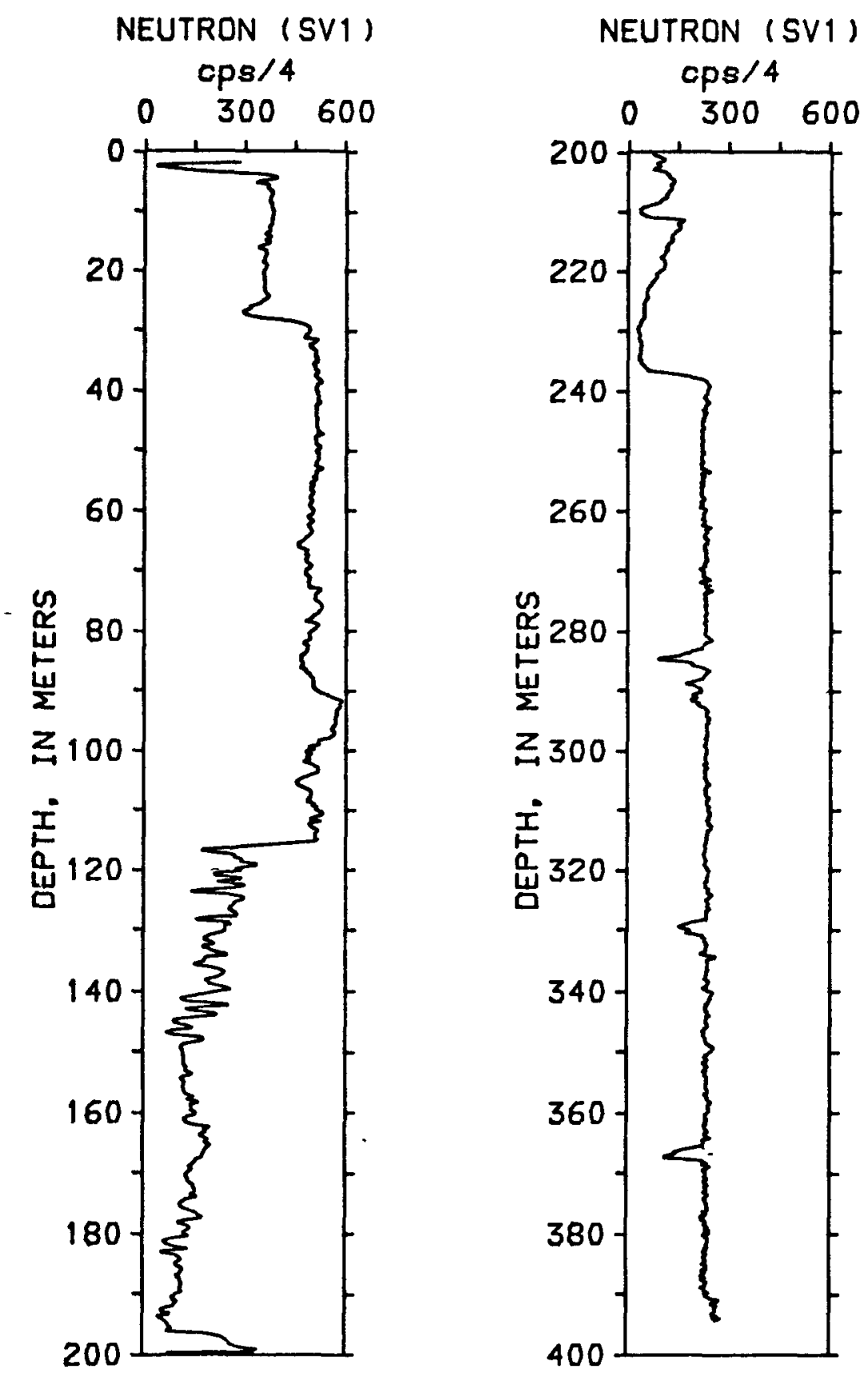

F1gure A6.--Neutron well 108 for dr111 hole SV1. Units are in cycles/second (cps/4). 

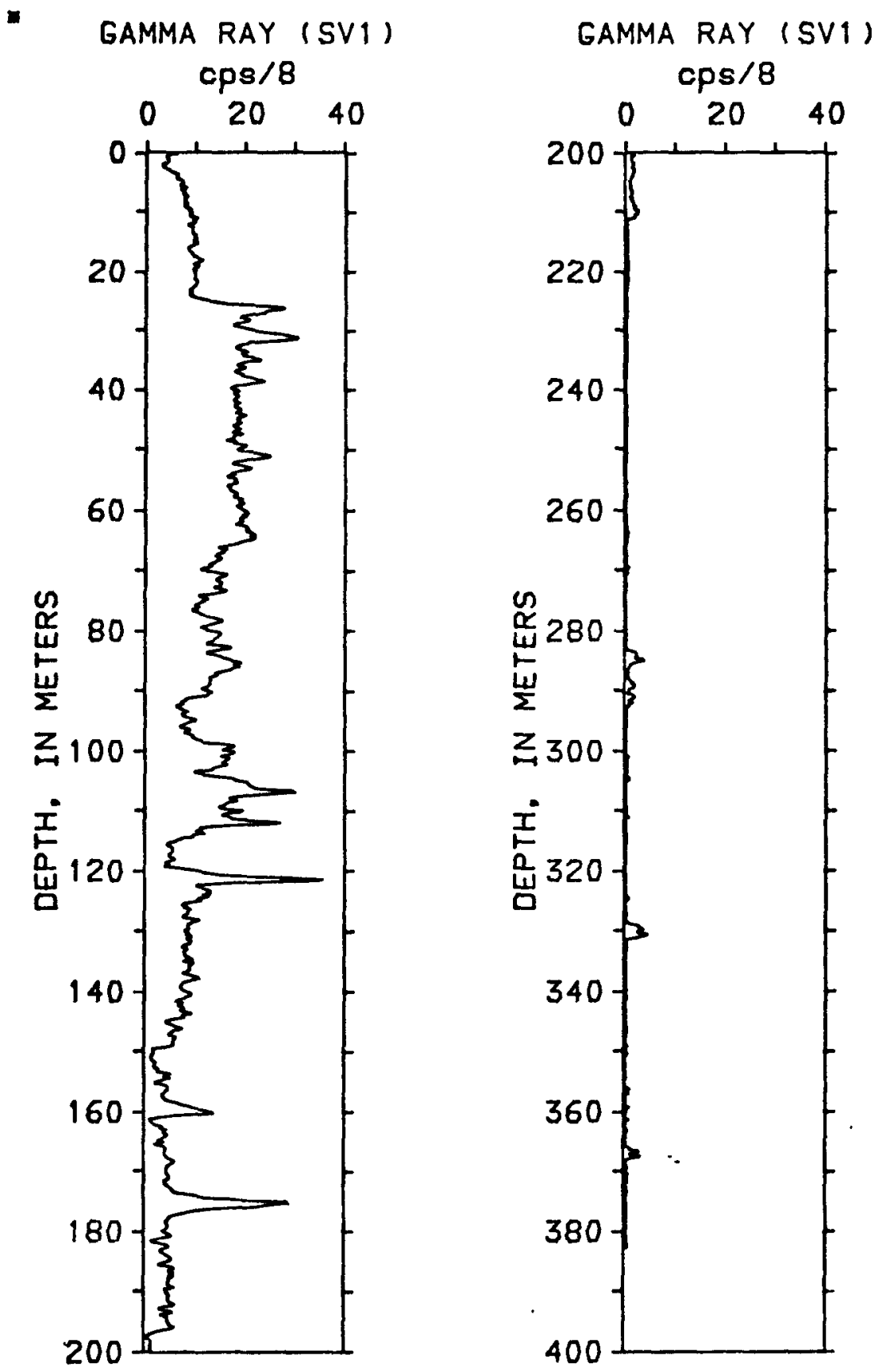
Figure A7.--Gamma ray well logs for drill hole sV1. Units are in
cycles/second $(\mathrm{cps} / 8)$. 


\begin{abstract}
APPENDIX B
Geophysical Well Logs from DOE Salt Valley No. 2 Drill Hole (SV2)
\end{abstract}



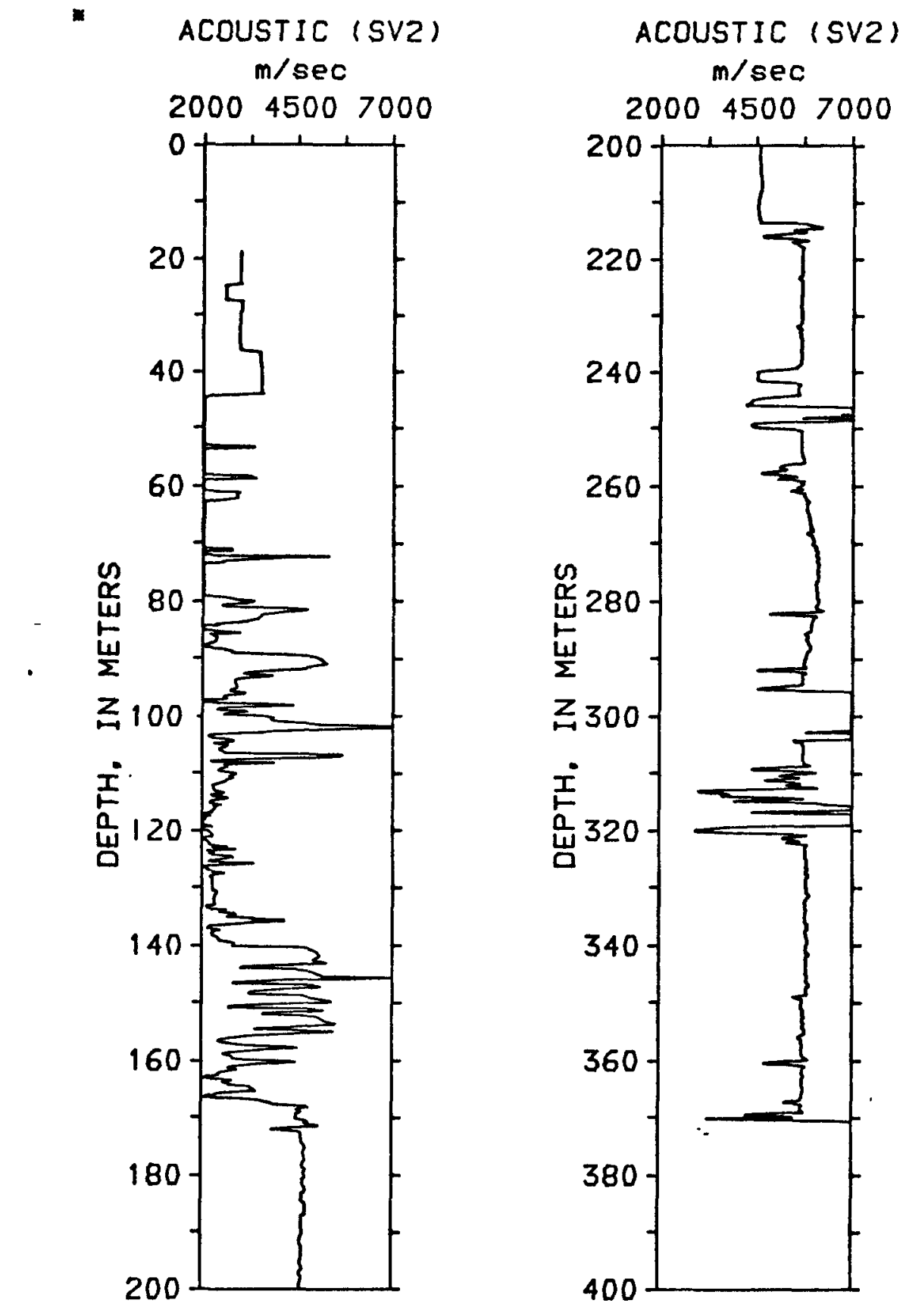

Figure Bi.--Acoustic velocity well log for drill hole sv2. Units are in meters/second $(\mathrm{m} / \mathrm{sec})$. 

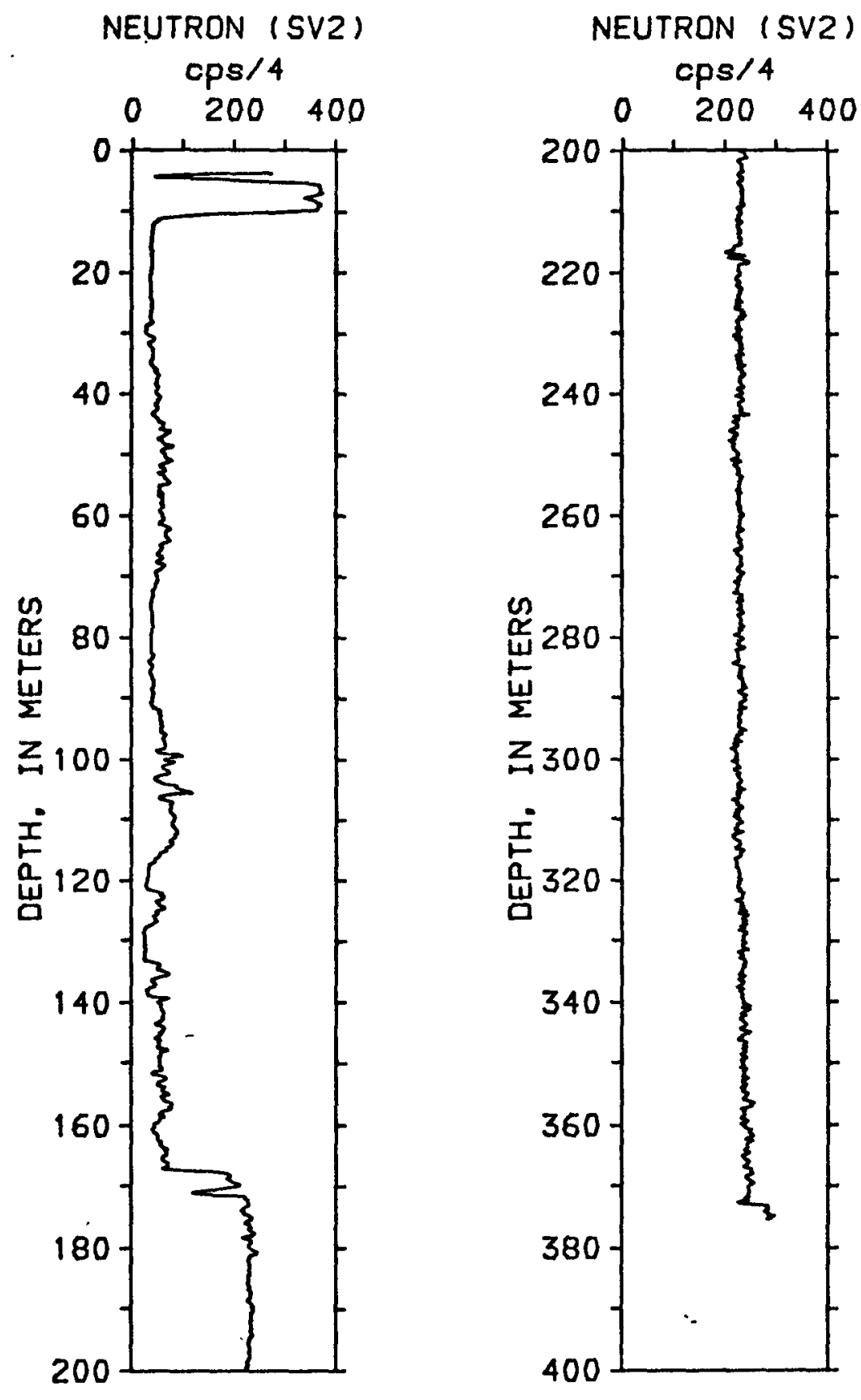

F1gure B2.--Neutron well 108 for drill hole SV2. Un1ts are in cycles/second (cps/4). 

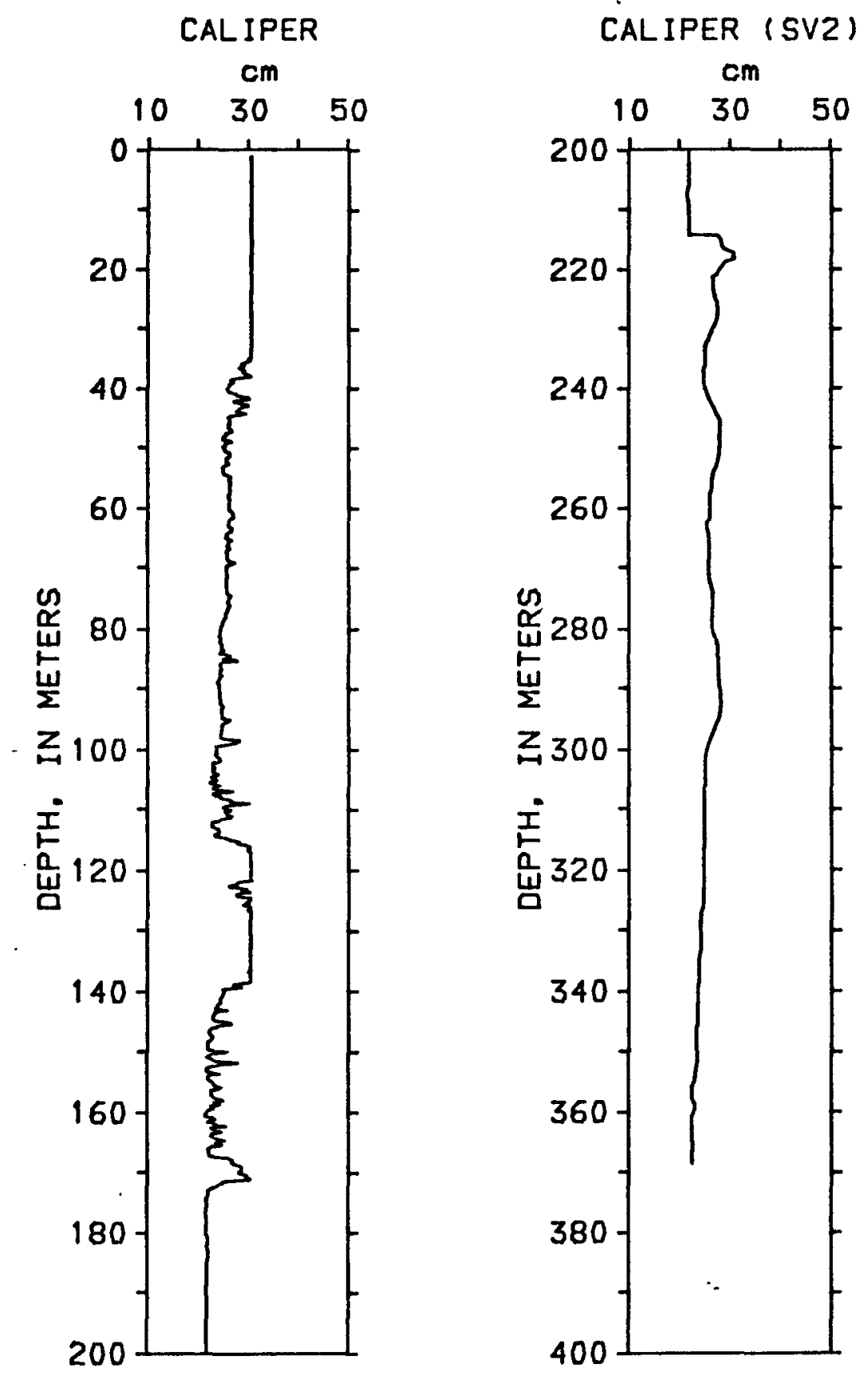

Figure B3.--Caliper well $\log$ for drill hole SV2. Units are In centimeters
(cm). 
$x$

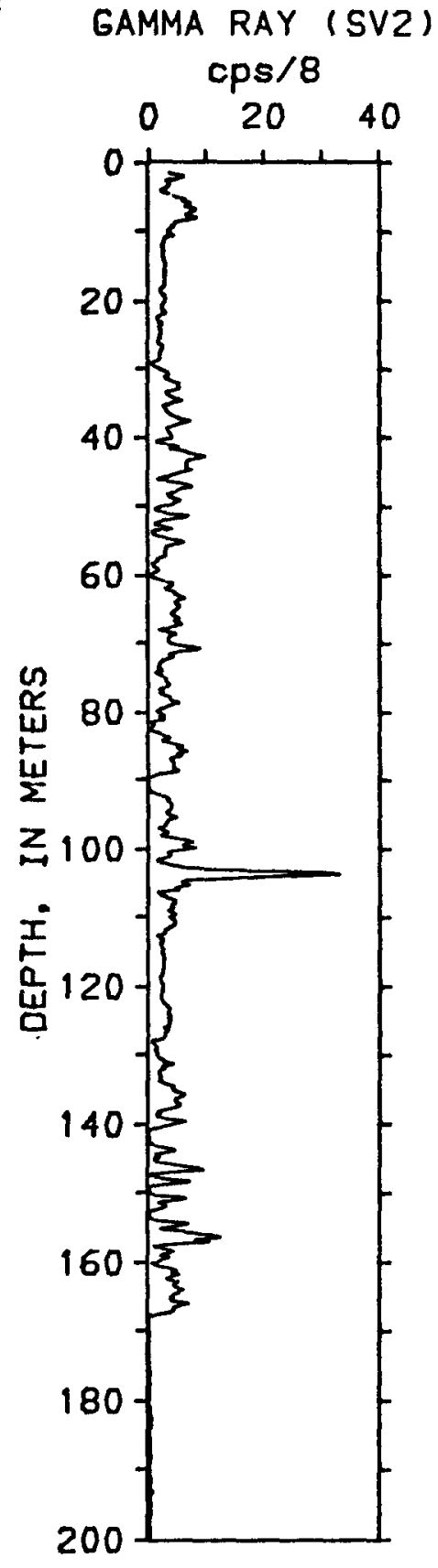

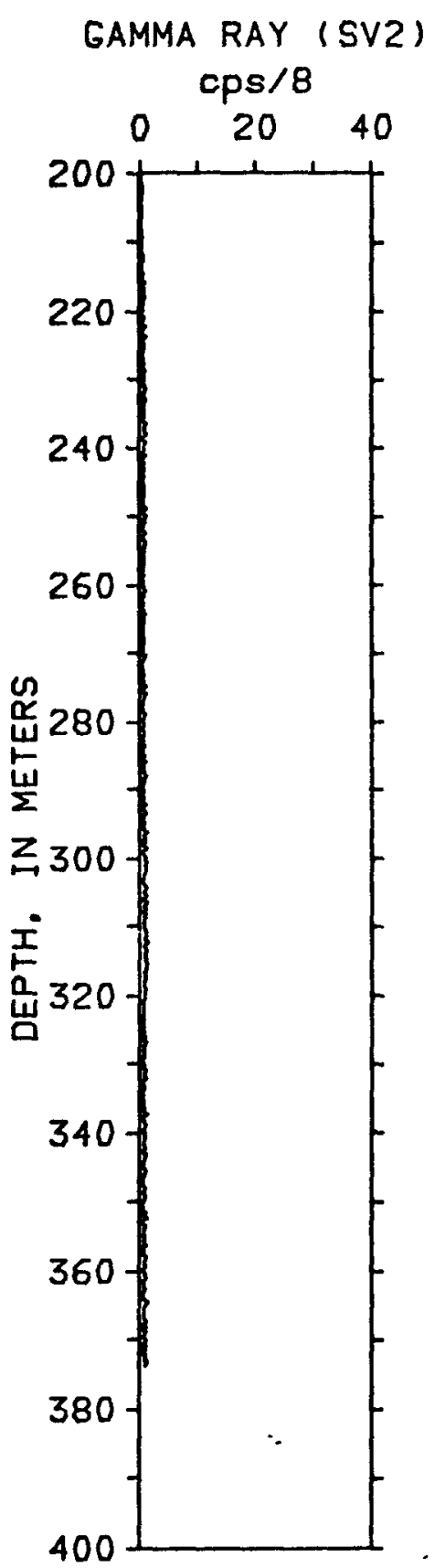

Figure B4.--Gamma ray well $\log$ for drill hole SV2. Units are in cycles/second $(\mathrm{cps} / 8)$. 


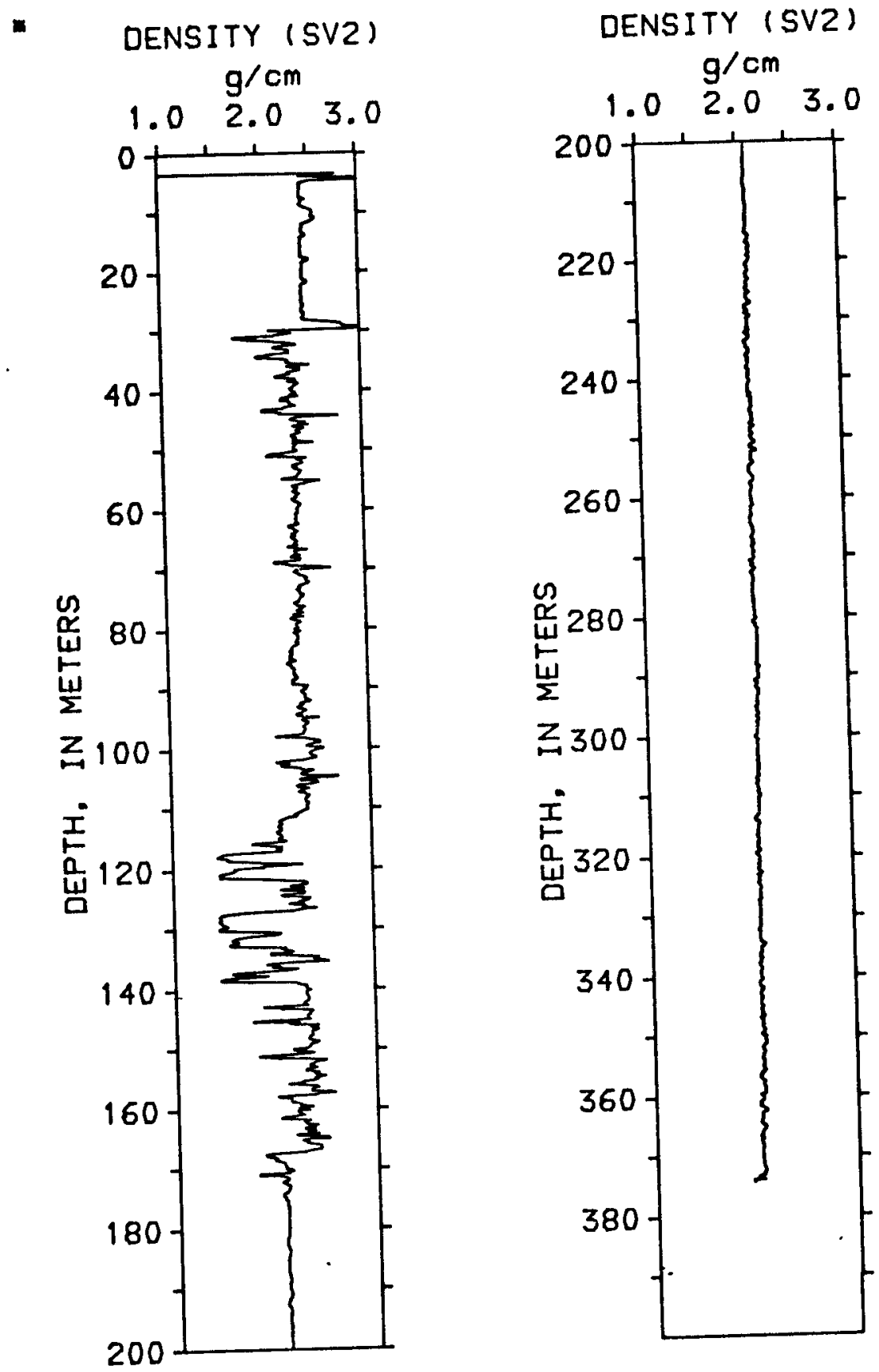

Figure B5.--Density well $\log$ for drill hole SV2. Units are in grams/centimeters ${ }^{3}\left(\mathrm{~g} / \mathrm{cm}^{3}\right)$. 

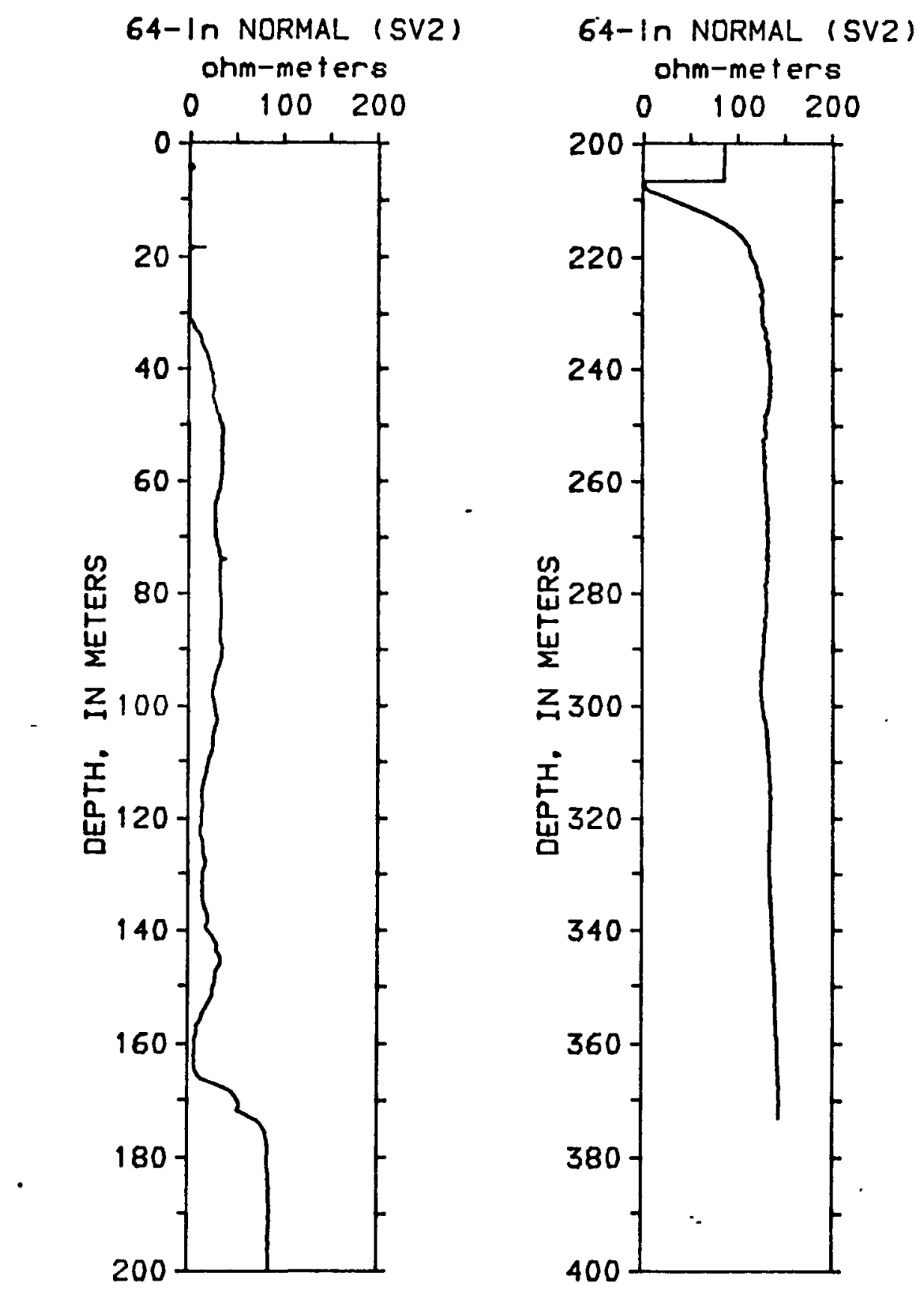

Figure B6.--Normal resistivity well $\log (64 \mathrm{ln})$ for dr1ll hole sv2. Units are in ohm-meters. 

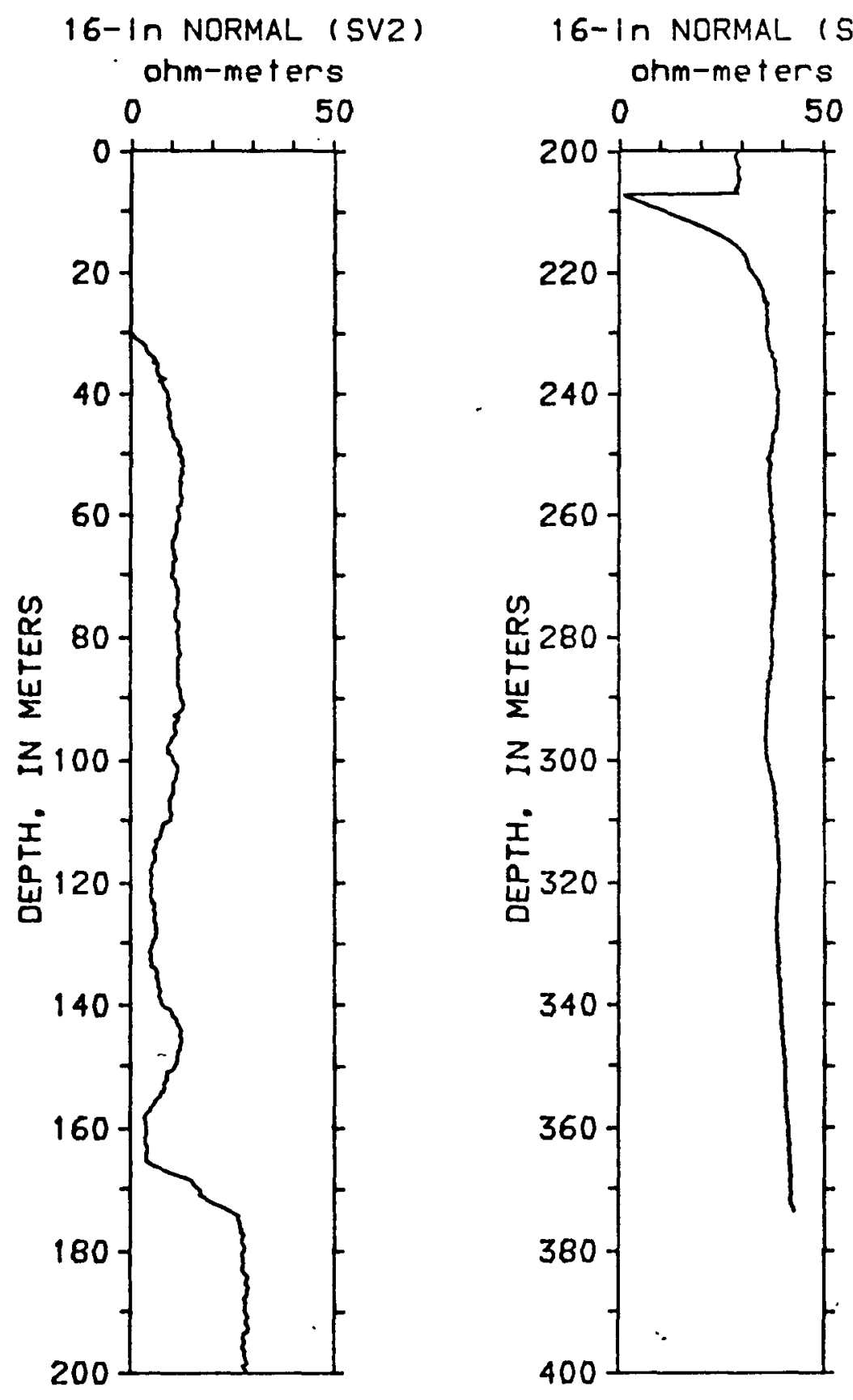

Flgure B7.--Normal resistivity well $\log (16 \mathrm{ln})$ for dr111 hole SV2. Units are in ohm-meters. 


\section{APPENDIX C}

Geophysical Well Logs from DOE Salt Valley No. 3 Drill Hole (SV3) 

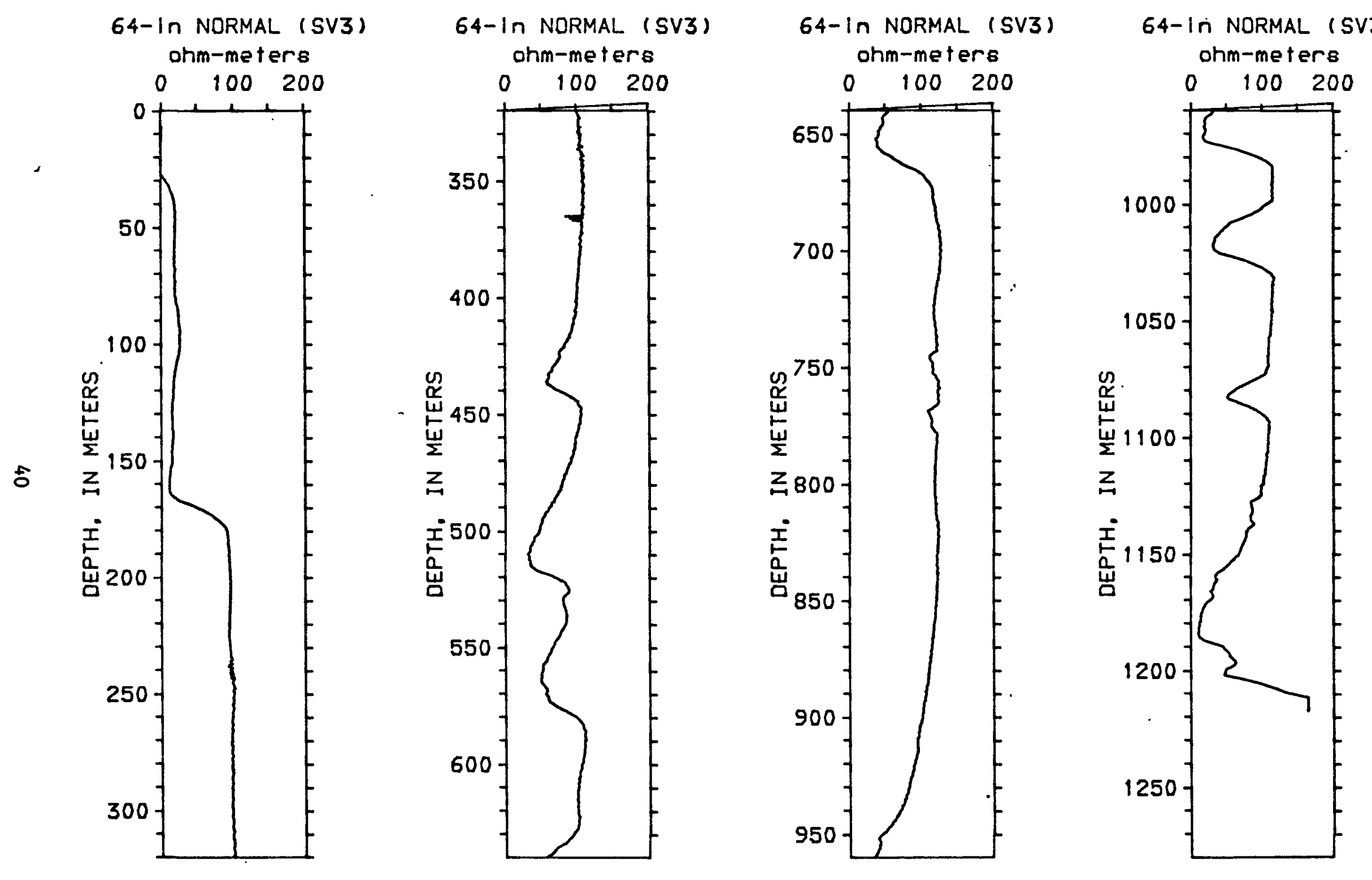

Figure C1.--Normal resistivity well $\log (64 \mathrm{ln})$ for drill hole sv3. Units are in ohm-meters. 

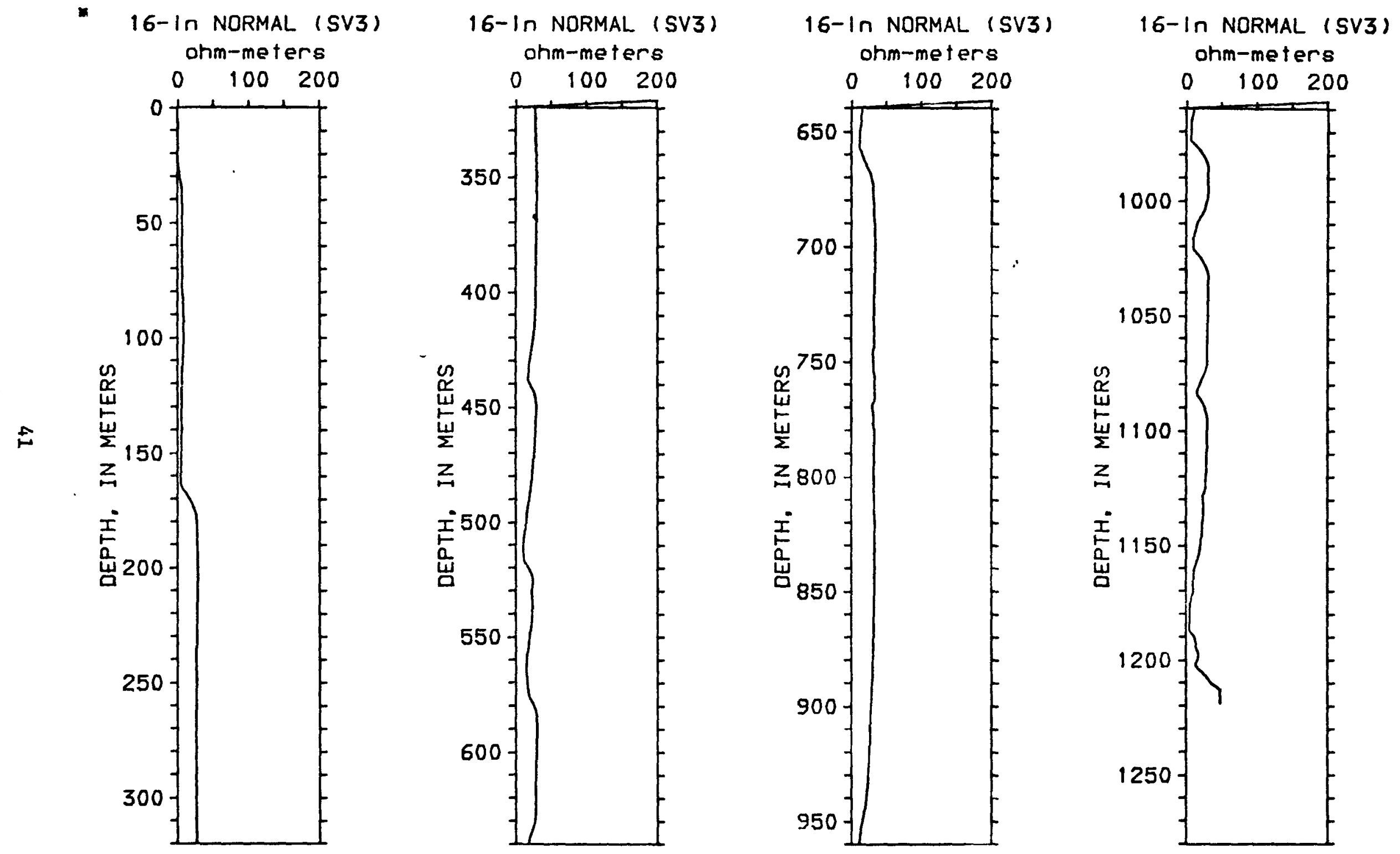

Figure C2.--Normal resistivity well logs $(16 \mathrm{ln})$ for drill hole sv3. Units are In ohm-meters. 

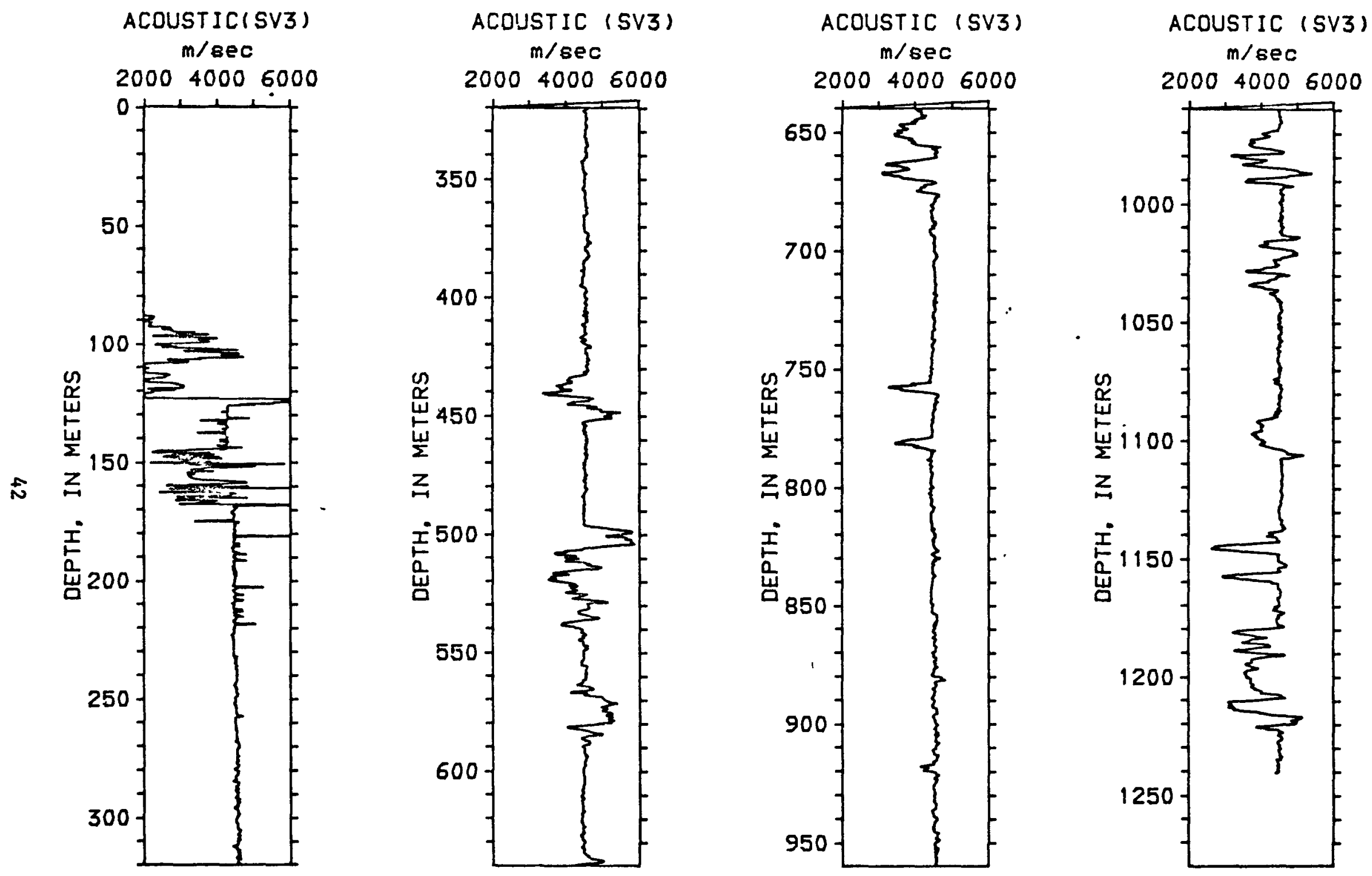

Figure C3.--Acoustic velocity well log for drill hle sv3. Units are in meter $8 /$ second $(\mathrm{m} / \mathrm{sec})$. 

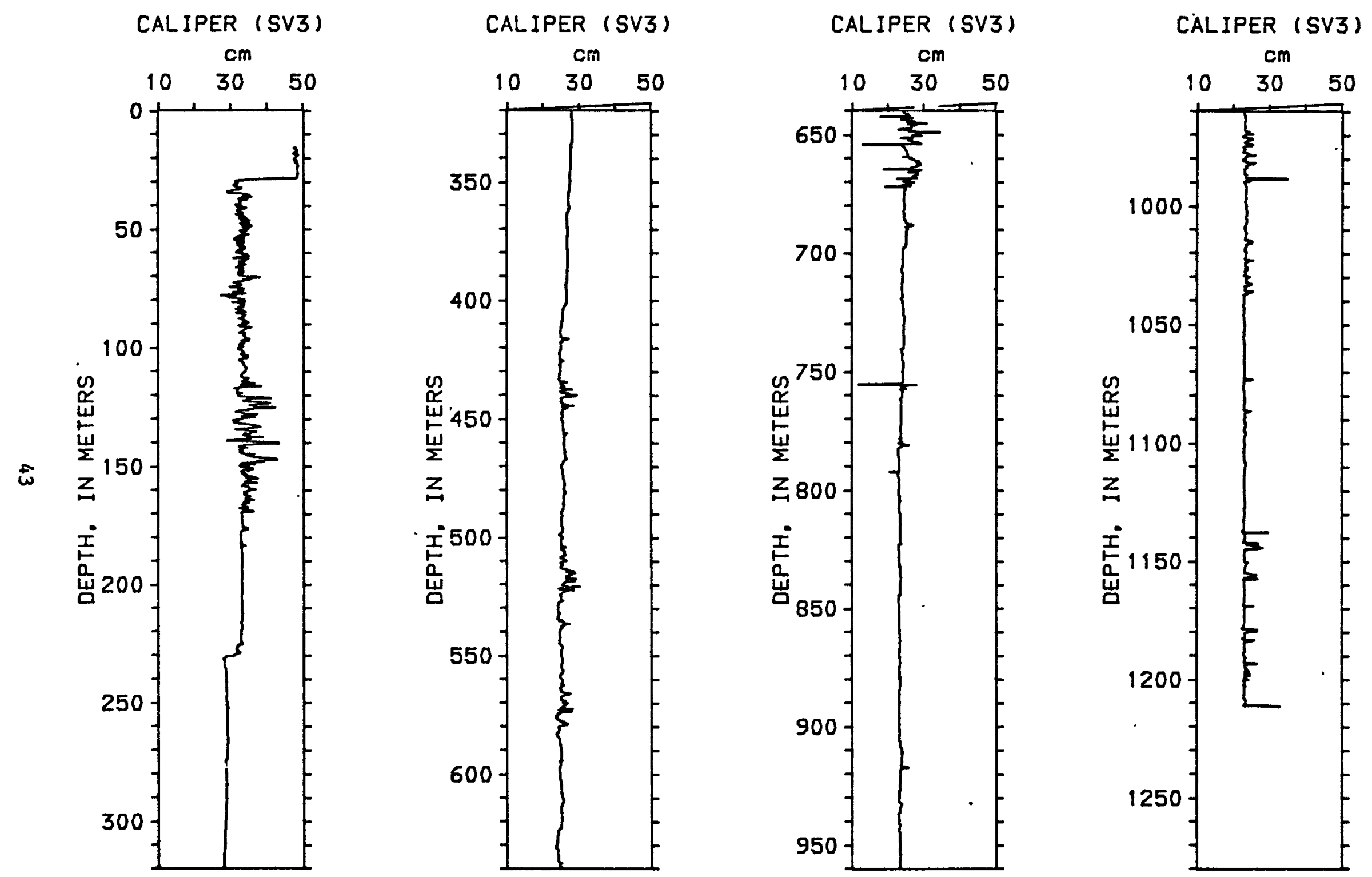

Figure C4.--Callper well 108 for dr1ll hole SV3. 'Units are in centimeters (cm). 

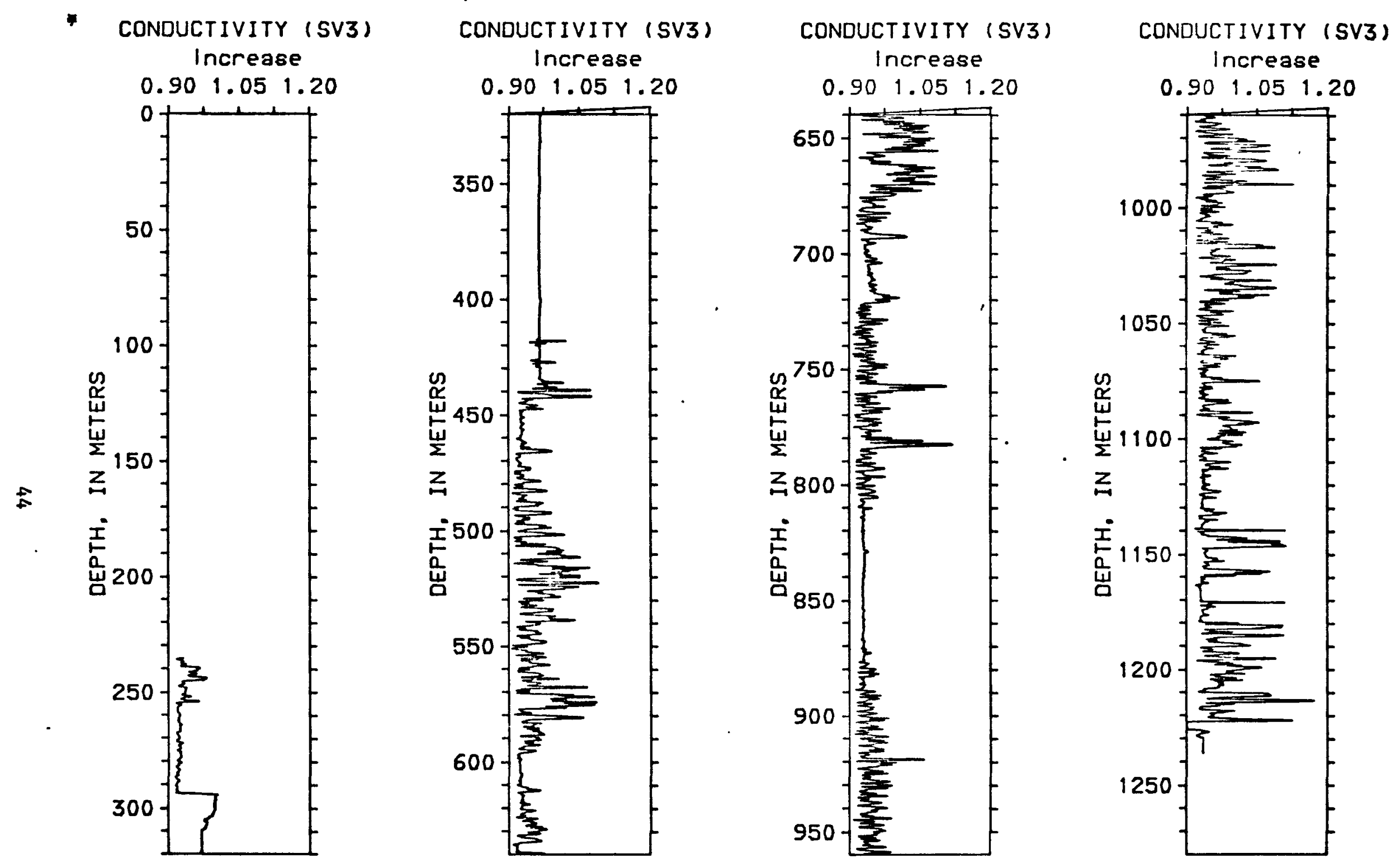

Figure C5.--Conductivity well $10 \mathrm{~g}$ for drill hole SV3. Units are uncalibrated with increasing conductivity to the right. 

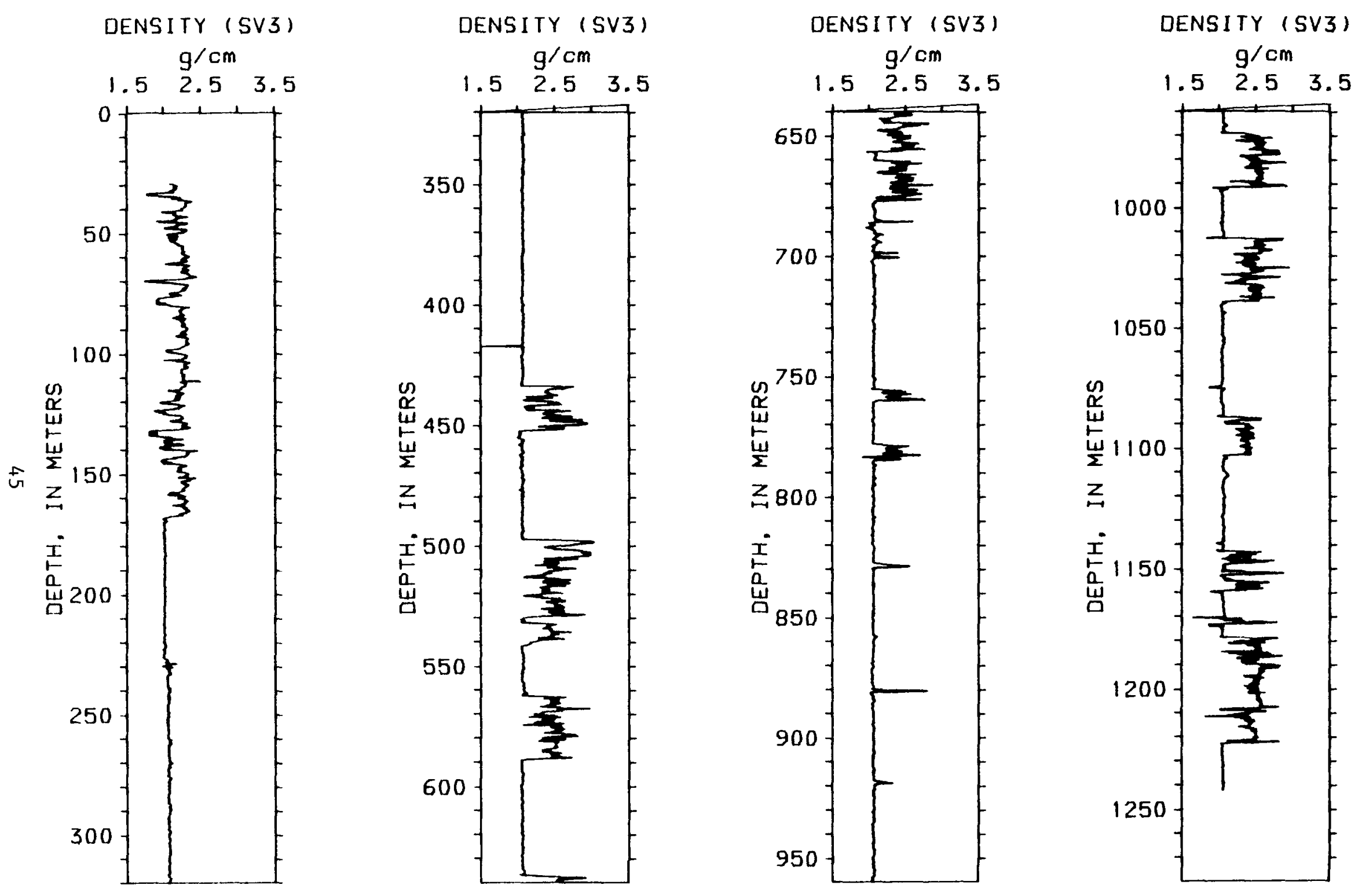

Figure C6. -Density well log for drill hole sv3. Units are in grams/cubic centimeter $\left(\mathrm{g} / \mathrm{cm}^{3}\right)$. 

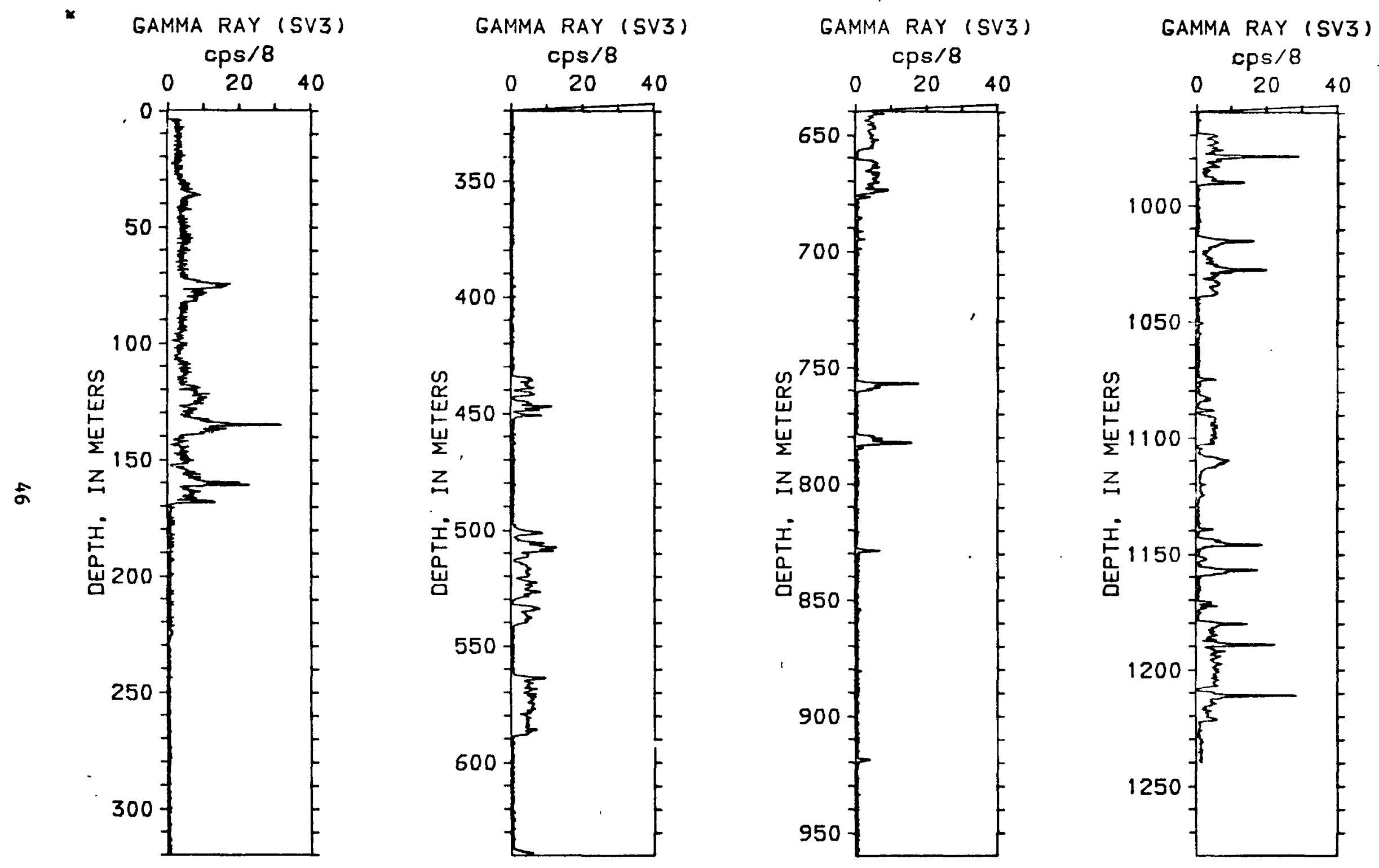

Pigure C7.- Gamma ray well log for drill hole sv3. Un1ts are in
counts/second $(\operatorname{cps} / 8)$. 

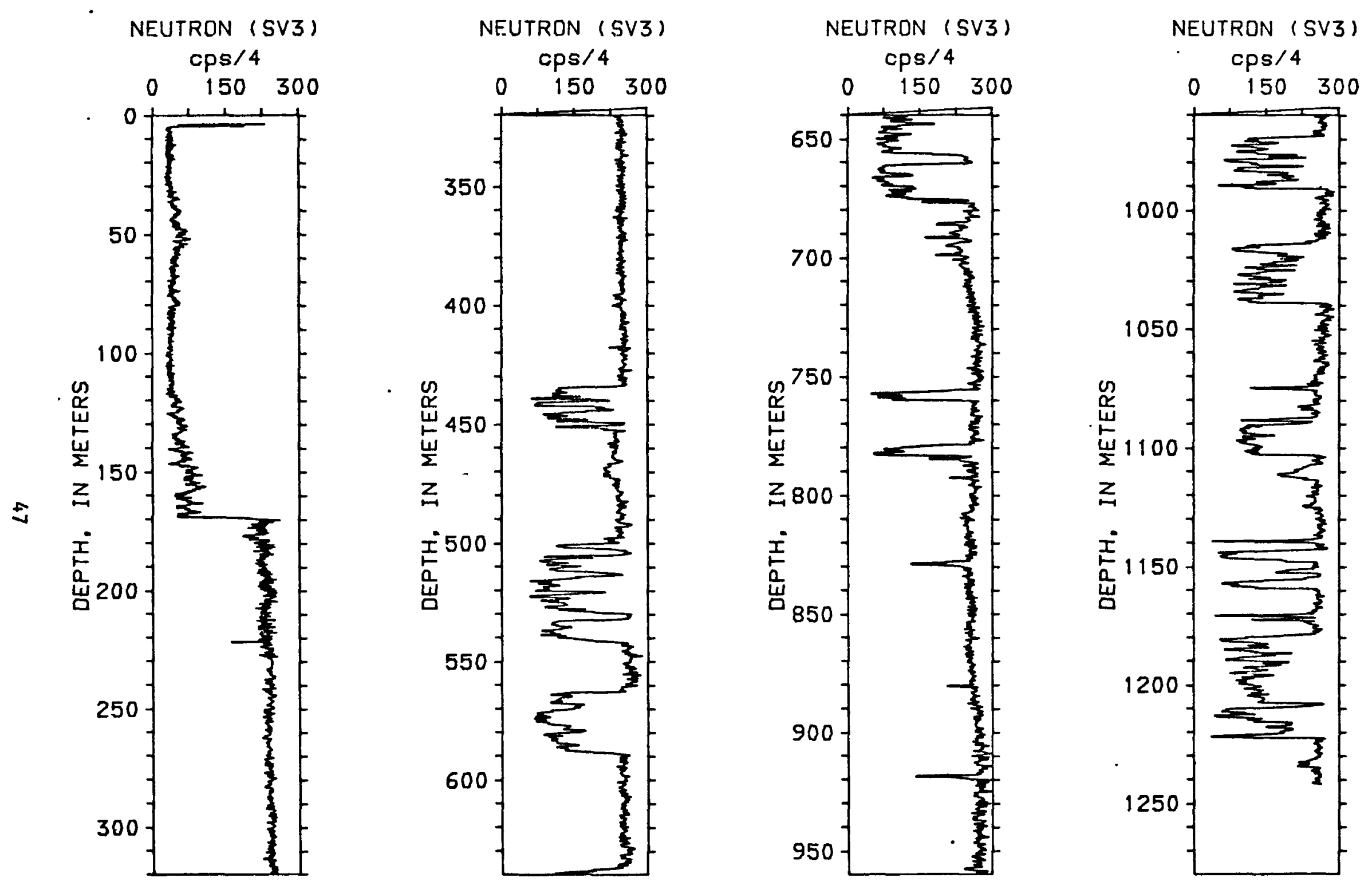

Figure C8.--Neutron well log for drill hole sV3. Units are in counts/second (cps/4) 


\section{APPENDIX D}

Computer-Assisted Interpretation of Geophysical Well Logs from Drill Hole SV3 

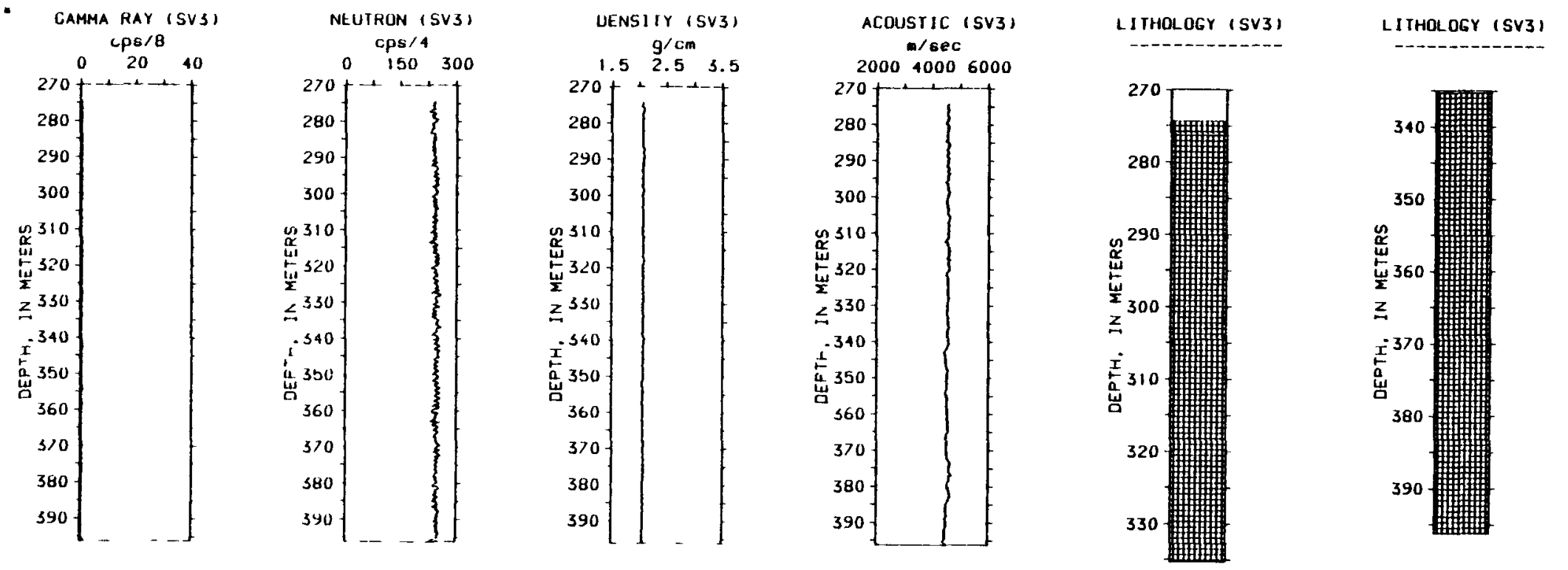

LEGEND

Figure D2.--Gamma-ray, neutron, density, and acoustic-velocity logs, and computer-assisted lithologic interpretation for the depth interval 275-396 m in SV3. 


(GAMMA RAY (SVB)
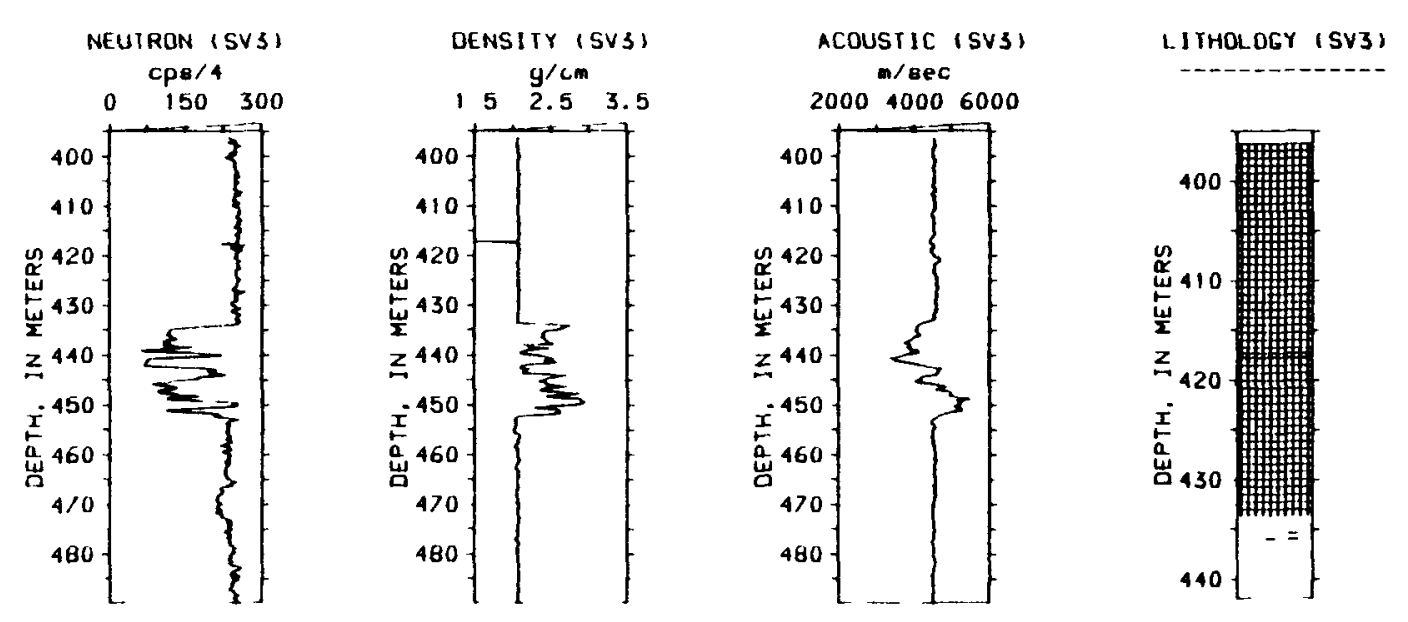

LITHOLOGY (SV3)

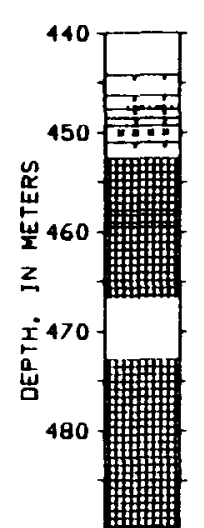

Figure

D 3. - -Gamma-ray, neutron,

density, and and acoustic-velocity logs, and computer-assisted 11thologic interpretation for the depth interval $396-490 \mathrm{~m}$ in SV 3 .
LEGEND

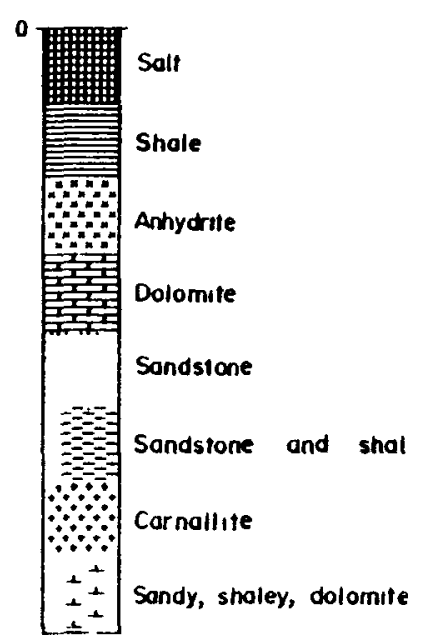




GAHAHA RAY (SV3)
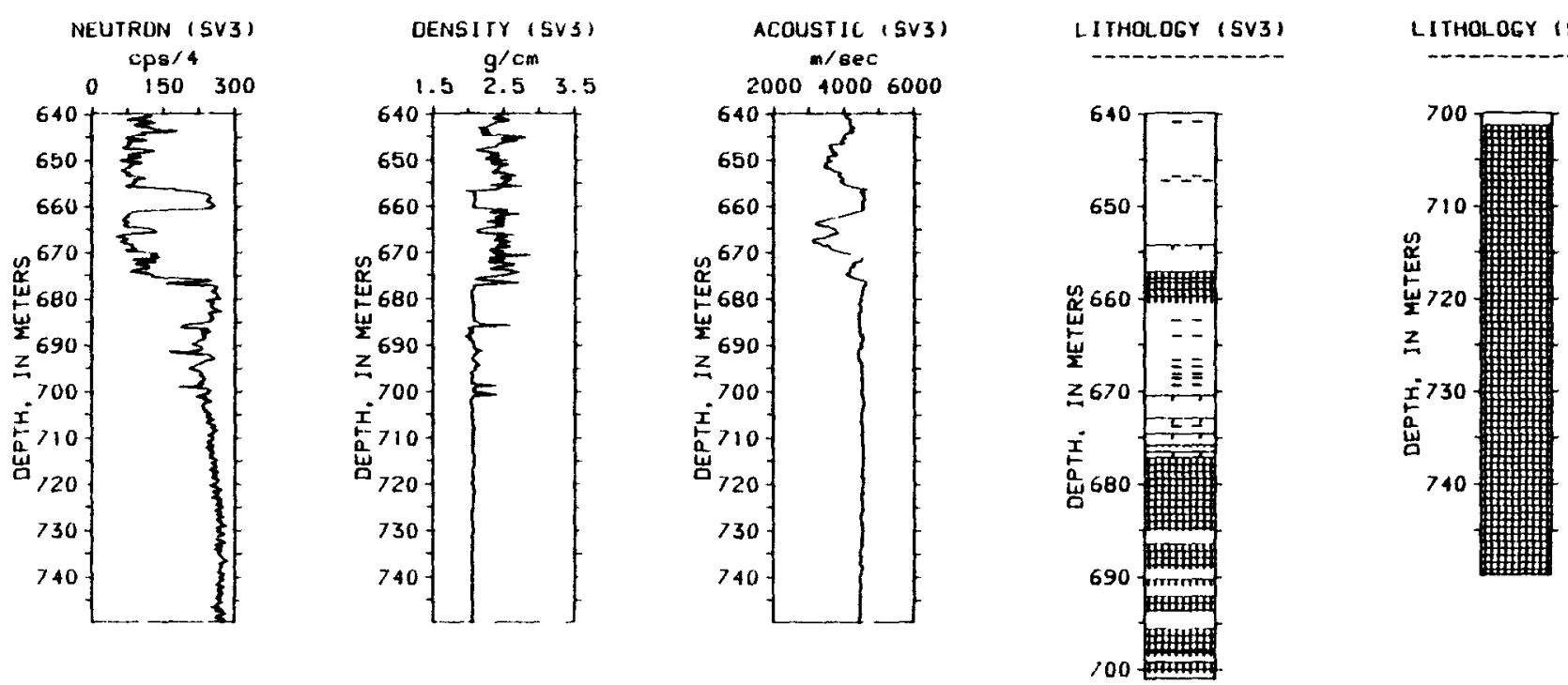

LEGEND

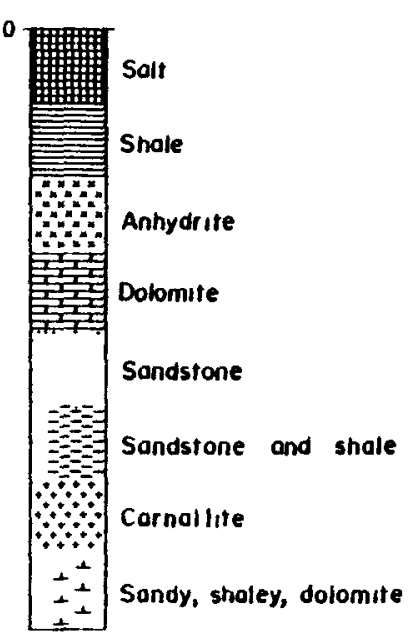

Figure D5.--Gamma-ray, neutron, density, and acoustic-velocity logs, and computer-assisted lithologic interpretation for the depth interval $640-750 \mathrm{~m}$ in SV3. 

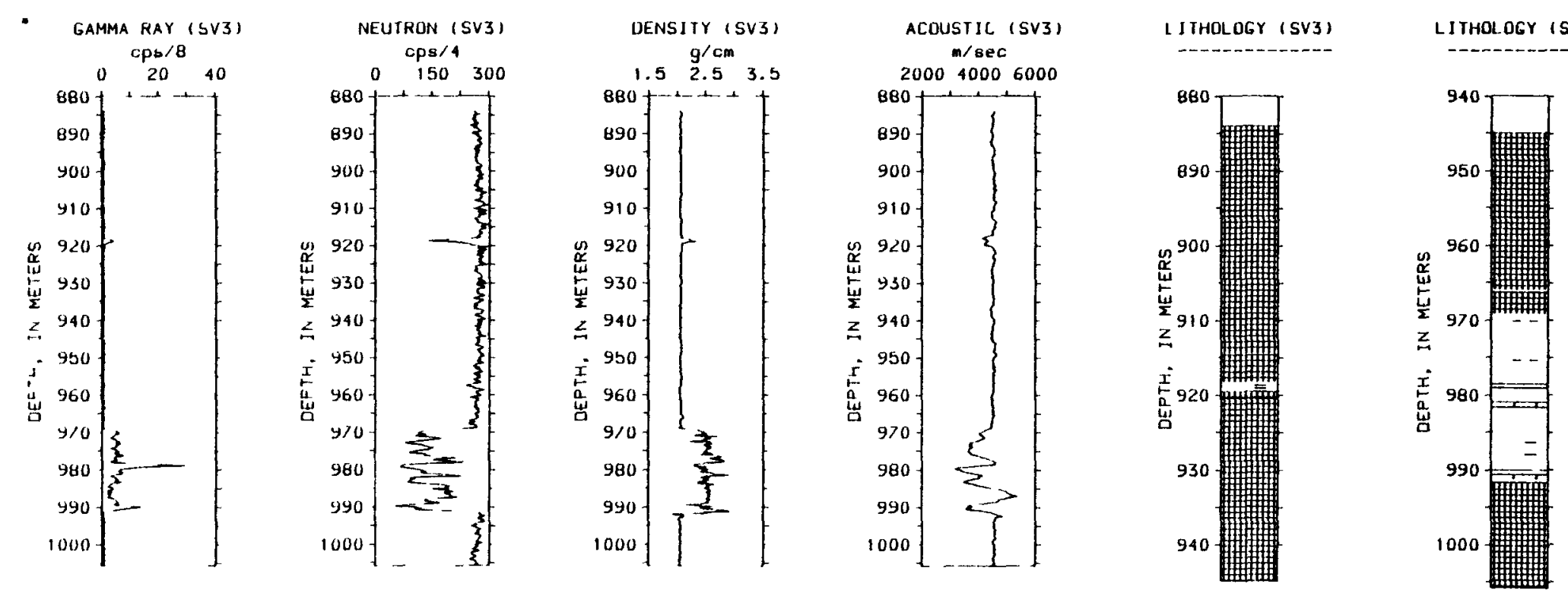

LEGEND

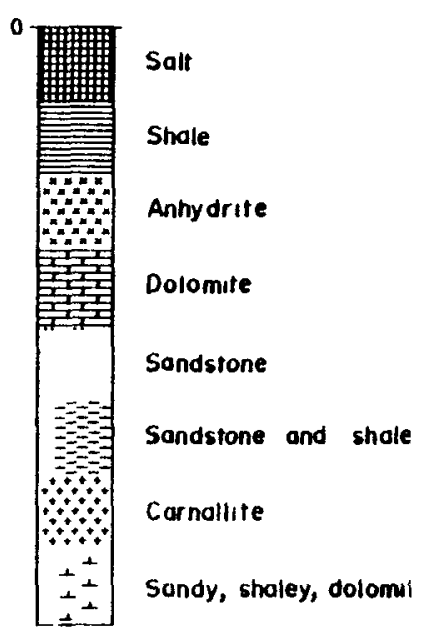

Figure D7.--Gamma-ray, neutron, density, and acoustic-velocity logs, and computer-assisted lithologic interpretation for the depth interval $884-1006 \mathrm{~m}$ in SV 3 . 

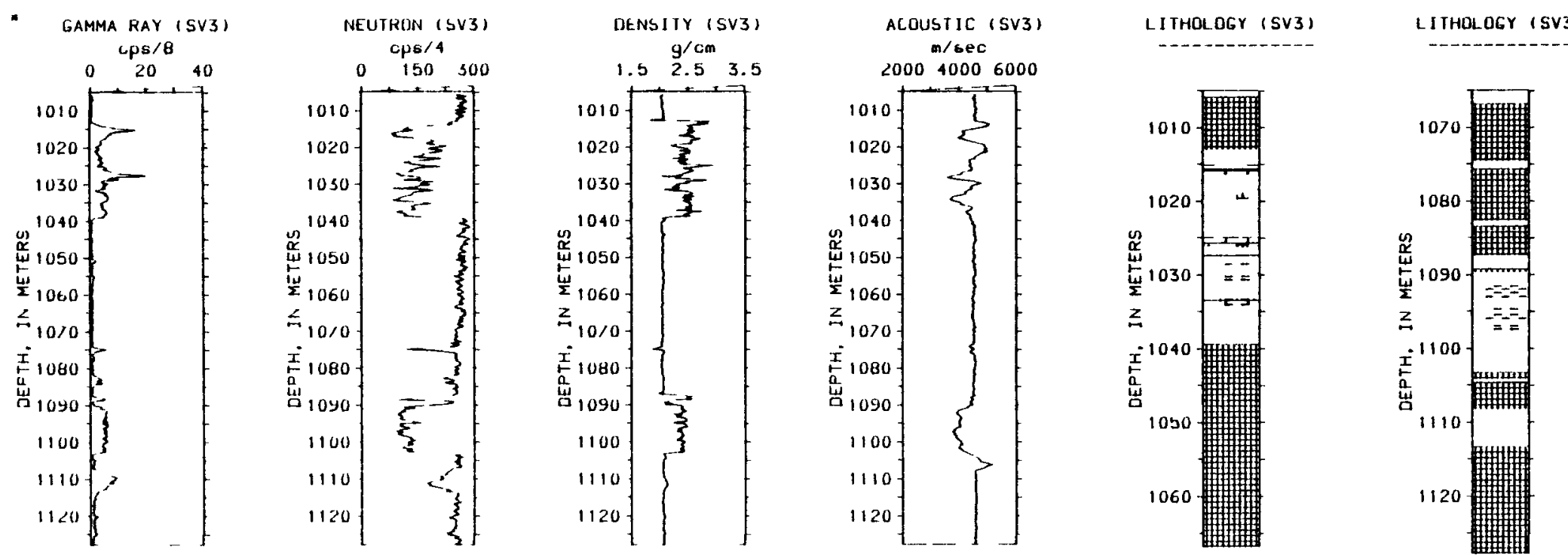

LEGEND

Figure D8. - Camma-ray, neutron, density, and acoustic-velocity logs, and computer-assisted Iithologic interpretation for the depth interval 1006-1128 $\mathrm{m}$ in SV3. 

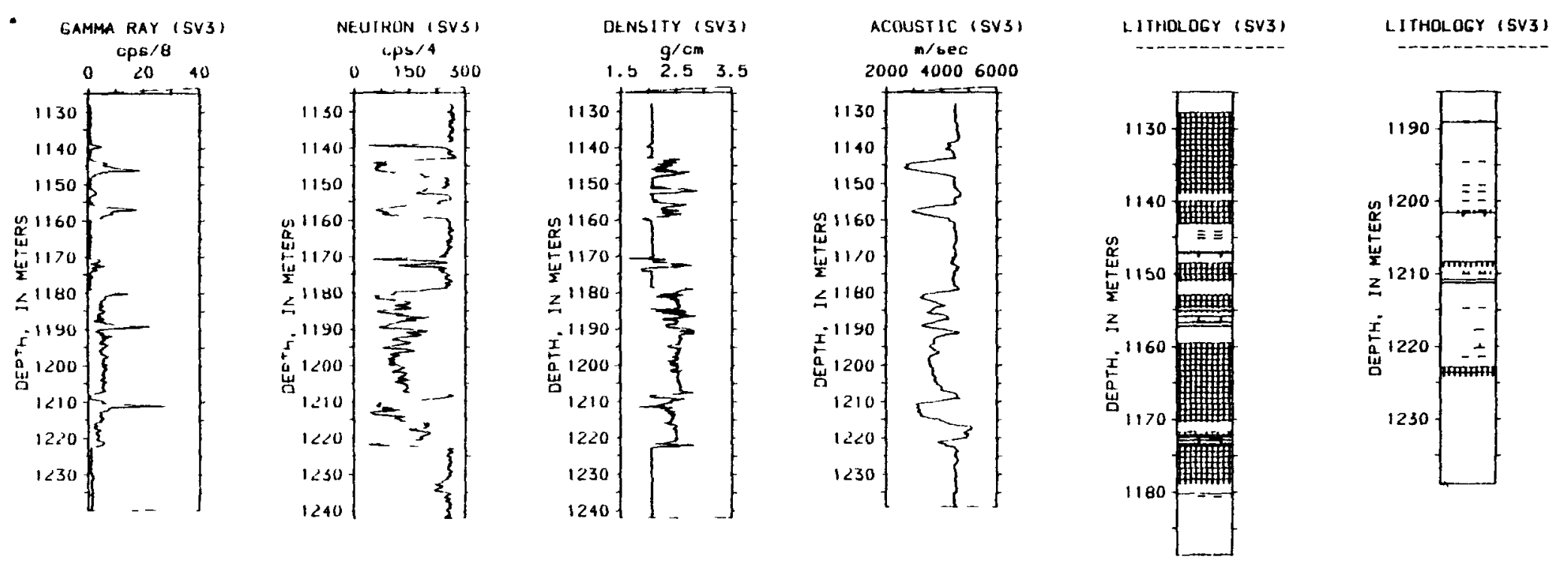

LEGEND

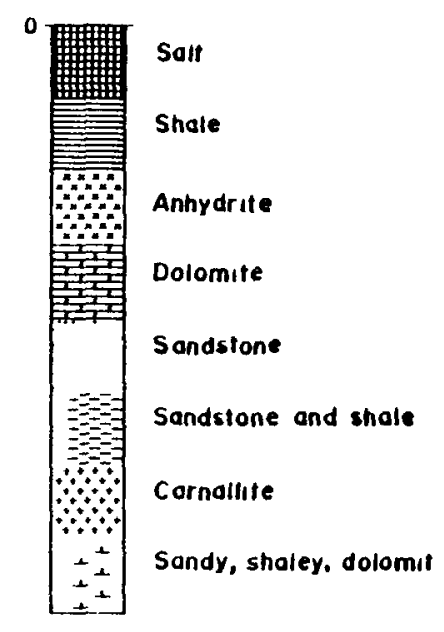

Figure D9.--Gamma-ray, neutron, density, and acoustic-velocity logs, and computer-assisted lithologic interpretation for the depth interval 1128-1242 $\mathrm{m}$ in SV3. 


$\begin{array}{cc}\text { Upper } & \text { Lower } \\ \text { Depth } & \text { Depth } \\ 444.2 & 444.3 \\ 446.3 & 446.6 \\ 447.7 & 414.1 \\ 448.6 & 449.5 \\ 451.0 & 451.8 \\ 498.0 & 498.4 \\ 498.9 & 499.5 \\ 523.3 & 523.4 \\ 525.6 & 525.9 \\ 528.3 & 579.2 \\ 535.8 & 536.1 \\ 562.9 & 563.2 \\ 567.5 & 568.1 \\ 578.1 & 579.5 \\ 587.9 & 588.4 \\ 654.2 & 654.3 \\ 670.5 & 671.0 \\ 672.9 & 673.1 \\ 674.6 & 674.8 \\ 676.0 & 676.7 \\ 759.5 & 759.7 \\ 880.5 & 881.0 \\ 980.9 & 981.7 \\ 990.7 & 991.1 \\ 1015.8 & 1016.0 \\ 1025.0 & 1025.7 \\ 1033.5 & 1033.7 \\ 1146.9 & 1147.1 \\ 1147.2 & 1147.5 \\ 1155.9 & 1156.2 \\ 1172.2 & 1172.4 \\ 1172.5 & 1172.8 \\ 1173.0 & 1173.1 \\ 1201.0 & 1201.8 \\ & \end{array}$

Table D1.--Depth interval in drill hole 3 chosen by the computer to contain the well log response values in Table 2 that are indicative of dolomite. 


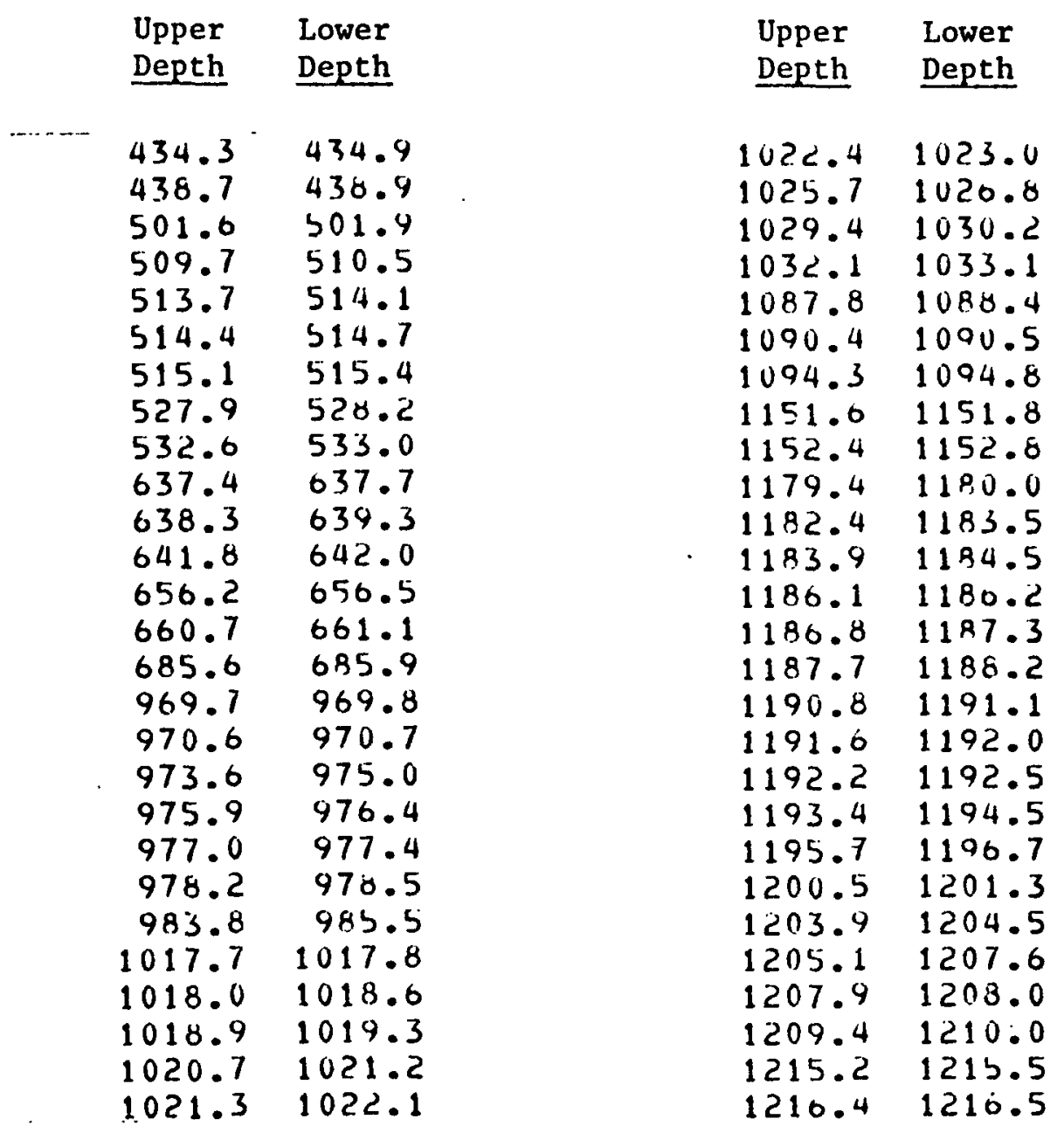

Table D2.--Depth interval in drill hole 3 chosen by the computer to contain the well $\log$ response values in Table 2 that are indicative of sandstone. 


\begin{tabular}{ll} 
Upper & Lower \\
Depth & Depth \\
\hline & \\
& \\
& \\
435.2 & 435.7 \\
435.6 & 436.3 \\
438.4 & 438.5 \\
438.9 & 439.2 \\
447.1 & 447.4 \\
450.7 & 450.9 \\
500.6 & 501.6 \\
505.3 & 505.4 \\
516.9 & 517.3 \\
519.0 & 519.3 \\
526.3 & 576.9 \\
533.0 & 535.0 \\
537.6 & 537.8 \\
537.9 & 538.4 \\
575.2 & 575.6 \\
575.7 & 575.9 \\
580.9 & 581.0 \\
585.8 & 586.1 \\
640.3 & 640.5 \\
640.6 & 641.2 \\
642.5 & 642.6 \\
646.3 & 646.4 \\
646.6 & 647.6 \\
661.4 & 661.5 \\
662.1 & 662.9 \\
663.0 & 663.2 \\
663.3 & 663.5 \\
663.8 & 664.4 \\
666.4 & 666.8 \\
667.1 & 667.6 \\
667.9 & 668.2 \\
668.4 & 668.8 \\
669.1 & 670.0 \\
673.5 & 673.9 \\
779.6 & 780.1 \\
780.4 & 781.8 \\
782.1 & 782.2 \\
783.1 & 783.3 \\
969.8 & 970.4 \\
970.0 & 970.7 \\
973.5 & 973.6 \\
975.1 & 975.6
\end{tabular}

Upper Lower

Depth Depth

Table D3.--Depth interval in drill hole 3 chosen by the computer to contain the well log response values in Table 2 that are indicative of sandstone (dolomitic (?)), and shale. 


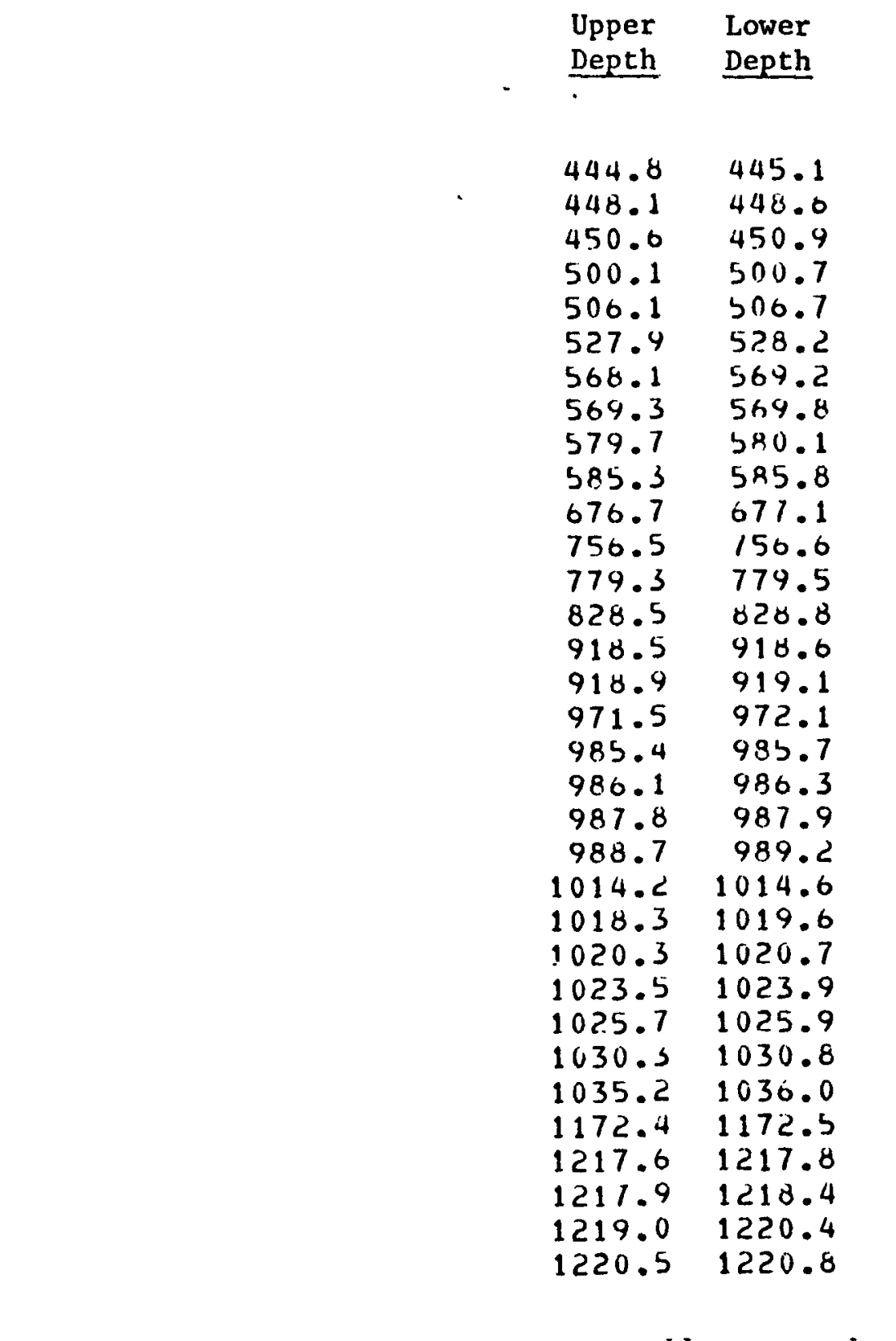

Table D4.--Depth interval in drill hole 3 chosen by the computer to contain the well fog response values in Table 2 that are indicative of sandy and shaley dolomite (calcite cemented dolomitic sandstone (?)). 


\begin{tabular}{lr}
$\begin{array}{l}\text { Upper } \\
\text { Depth }\end{array}$ & \multicolumn{1}{l}{$\begin{array}{l}\text { Lower } \\
\text { Depth }\end{array}$} \\
& \\
444.0 & 444.2 \\
449.5 & 450.1 \\
498.0 & 500.0 \\
880.5 & 880.8 \\
981.5 & 981.7 \\
991.1 & 991.3 \\
1013.1 & 1013.4 \\
1013.6 & 1014.0
\end{tabular}

Table D5.--Depth interval in drill hole 3 chosen by the computer to contain the well $\log$ response values in Table 2 that are indicative of anhydrite. 


$$
\begin{array}{rr}
\begin{array}{c}
\text { Upper } \\
\text { Depth }
\end{array} & \begin{array}{r}
\text { Lower } \\
\text { Depth }
\end{array} \\
\hline & \text {. } \\
168.6 & 169.0 \\
1074.8 & 1075.3 \\
1139.4 & 1139.9 \\
1170.5 & 1170.8
\end{array}
$$

Table D6.--Depth interval in dri1l hole 3 chosen by the computer to contain the well $\log$ response values in Table 2 that are indicative of carnallite. 


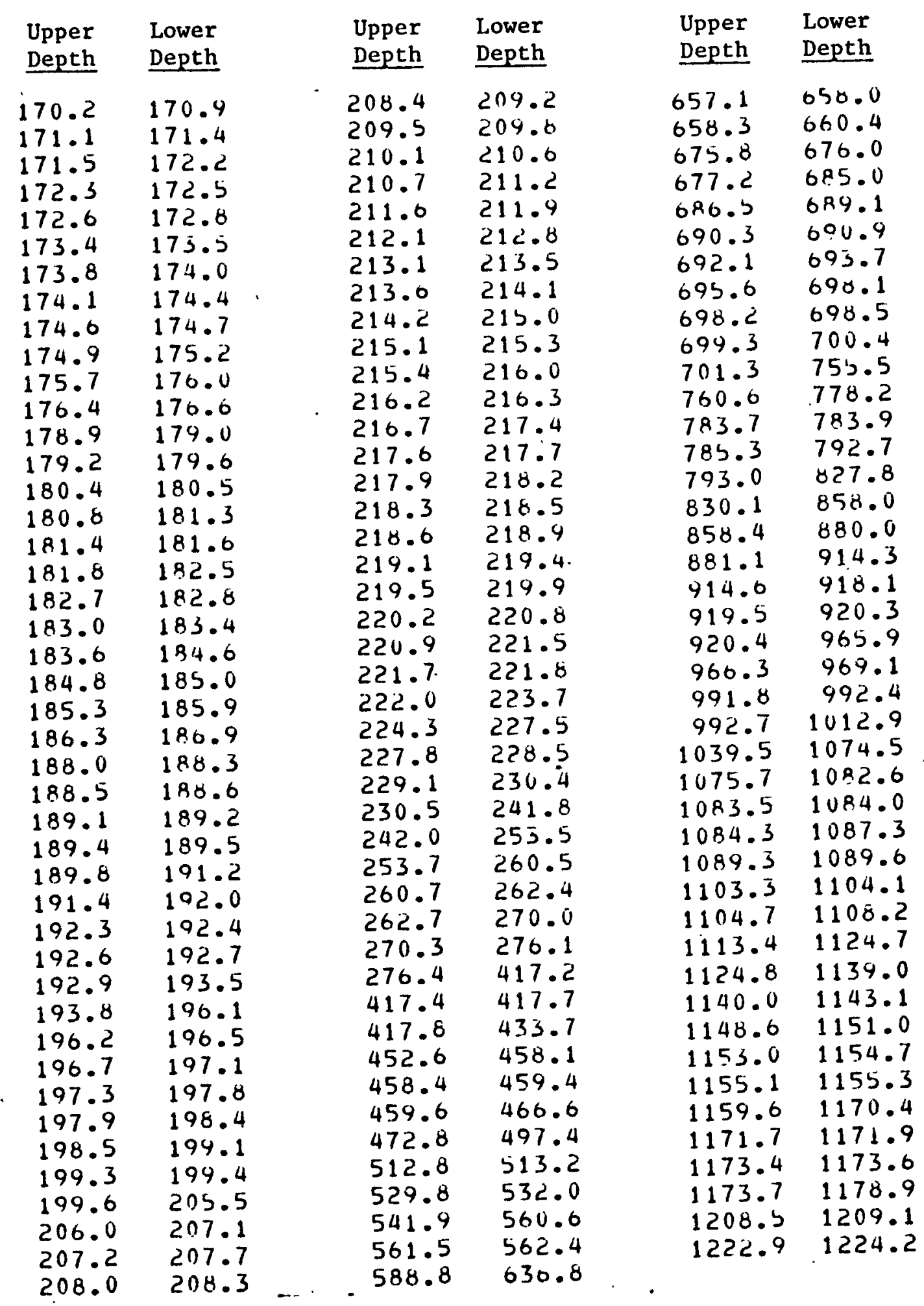

Table D7.--Depth interval in drill hole 3 chosen by the computer to contain the well log response values in Table 2 that are indicative of halite. 


\begin{tabular}{|c|c|}
\hline $\begin{array}{l}\text { Upper } \\
\text { Depth }\end{array}$ & $\begin{array}{l}\text { Lower } \\
\text { Depth }\end{array}$ \\
\hline$\cdot$ & \\
\hline $\begin{array}{l}757.1 \\
782.2 \\
978.5\end{array}$ & $\begin{array}{l}757.4 \\
782.8 \\
979.0\end{array}$ \\
\hline 990.1 & 990.2 \\
\hline 015.1 & . \\
\hline 1027. & 1028 \\
\hline 1156.7 & 1157.4 \\
\hline 1180. & 1180 \\
\hline 1189.1 & \\
\hline 1210.9 & 1211.1 \\
\hline 1211.4 & 1211.5 \\
\hline
\end{tabular}

Table D8.--Depth interval in drill hole 3 chosen by the computer to contain the well $\log$ response values in Table 2 that are indicative of black shale. 
RECEND MUTTC MAR 51981 